\author{
UNIVERSIDADE DE SÃO PAULO \\ FACULDADE DE MEDICINA DE RIBEIRÃO PRETO \\ DEPARTAMENTO DE PATOLOGIA
}

CRISTIANE TEFÉ DA SILVA

Interferência da dexametasona no ciclo pulmonar da infecção por Strongyloides venezuelensis em ratos Wistar 
CRISTIANE TEFÉ DA SILVA

\title{
Interferência da dexametasona no ciclo pulmonar da infecção por Strongyloides venezuelensis em ratos Wistar
}

\author{
Dissertação apresentada ao Departamento de \\ Patologia da Faculdade de Medicina de Ribeirão \\ Preto da Universidade de São Paulo para obtenção \\ do título de Mestre em Ciências Médicas. \\ Área de Concentração: Patologia \\ Opção: Patologia Experimental \\ Orientadora: Prof ${ }^{a}$. Dra. Simone G. Ramos
}

Ribeirão Preto

2008 
AUTORIZO A REPRODUÇÃO E DIVULGAÇÃO TOTAL OU PARCIAL DESTE TRABALHO, POR QUALQUER MEIO CONVENCIONAL OU ELETROONICO, PARA FINSS DE ESTUDO E PESQUISA, DESDE QUE CITADA A FONTE.

FICHA CATALOGRÁFICA

Tefé-Silva, Cristiane

Interferência da dexametasona no ciclo pulmonar da infecção por Strongyloides venezuelensis em ratos Wistar. Ribeirão Preto, 2008.

122 p. : il. ; $30 \mathrm{~cm}$

Dissertação de Mestrado, apresentada à Faculdade de Medicina de Ribeirão Preto/USP - Área de concentração: Patologia Experimental.

Orientadora: Ramos, Simone Gusmão.

1. Strongyloides venezuelensis, 2. Parasitas, 3. Pulmão, 4. Dexametasona 


\section{FOLHA DE APROVAÇÃO}

CRISTIANE TEFÉ DA SILVA

Interferência da dexametasona no ciclo pulmonar da infecção por STRONGYLOIDES VENEZUELENSIS em ratos Wistar

Dissertação de Mestrado apresentada à Faculdade de Medicina de Ribeirão Preto da Universidade de São Paulo para obtenção do título de Mestre em Ciências Médicas.

Área de concentração: Patologia Experimental.

Banca Examinadora

Prof. Dr.

Instituição: Assinatura:

Prof. Dr.

Instituição: Assinatura:

Prof. Dr.

Instituição: Assinatura: 


\section{DEDICATÓRIA}

Aos meus queridos e amados pais, Zote e Izabel que foram minha força nos momentos difíceis e com amor incondicional, me apoiaram e incentivaram a nunca desistir dos meus sonhos.

Ao meu irmão Mateus, pelo apoio durante todo o tempo que estive longe, essa distância nos uniu e sei que posso contar com você em todos os momentos de minha vida.

A vocês, que sempre confiaram na minha capacidade, dedico este trabalho. 


\section{AGRADECIMENTO ESPECIAL}

À minha orientadora Prof ${ }^{a}$ Dra. Simone Gusmão Ramos

Pela acolhida em seu laboratório, pela paciência e compreensão diante de minha inexperiência. Agradeço pelos ensinamentos que possibilitaram meu amadurecimento científico, intelectual e pessoal e pela confiança em minha capacidade.

"Se enxerguei mais longe, foi por estar de pé sobre os ombros de gigantes"

Isaac Newton 


\section{AGRADECIMENTOS}

"Meu refúgio, minha fortaleza, meu Deus, eu confio em ti"

À Profa Dra. Lúcia H. Faccioli, por aceitar participar da minha banca de mestrado. Pelas valiosas conversas, pela parceria e imensa contribuição científica para a realização desse trabalho.

Ao Prof. Dr. Marcos A. Rossi, que gentilmente sempre cedeu seu laboratório para realização das imagens, processamento de parte dos materiais e pelas valiosas sugestões científicas.

À Profa Dra. Marlene T. Ueta, pela disponibilidade de seu laboratório para a infecção dos animais e pelas discussões científicas.

Ao Prof. Dr. João Terra Filho, por aceitar tão prontamente participar da minha banca e pelas enriquecedoras sugestões.

À técnica Elaine M. Floriano, que desde o primeiro momento me acolheu no laboratório com muito afeto e carinho. Agradeço pela disponibilidade em ajudarme nos experimentos, no processamento dos materiais, na execução de técnicas, além da amizade e apoio em diversos momentos.

Um agradecimento especial à Daniela I. Souza pela oportunidade de dar continuidade ao seu trabalho e pelos ensinamentos compartilhados e a disposição em me ajudar sempre que precisei.

Ao Técnico João B. A. Oliveira pela eficiência durante as infecções dos animais realizadas no laboratório da UNICAMP.

Às secretárias do Departamento de Patologia, Neide T. Gonçalves, Rosângela C. N. Paiva, Edna Pio (in memorian), Camila L. Zambonini, pela gentileza, pela atenção, sempre dispostas a ajudar.

Às técnicas do laboratório de Cardiologia Celular e Molecular Lígia G. V. Santoro, Maria Helena Riul e Mônica A. Abreu, pela imensa colaboração durante todo o desenvolvimento do meu trabalho.

À técnica Denise Chesca, pela disposição e boa vontade a me ensinar imunoistoquímica.

Aos técnicos do Laboratório da Profa. Lúcia Faccioli, Carlos A. Sorgi pela dosagem das citocinas e a Érica V. Silva pelo auxílio para realização dos experimentos.

À Daniela Carlos pelo auxílio nas colorações e pelo apoio. 
À minha grande amiga Cristina T. B. Fontanezi agradeço pelos ensinamentos científicos compartilhados, por me ensinar muito do sei hoje, por me ajudar durante meus experimentos inclusive nos finais de semana. Agradeço pela amizade de 20 anos, pela cumplicidade, carinho, paciência e compreensão.

À minha amiga Mara Rúbia N. Celes, por me ensinar a pensar cientificamente, pelas longas discussões e contribuições científicas para o desenvolvimento do meu trabalho. Obrigada pela acolhida, pela amizade, pelo companheirismo nas alegrias e tristezas, pelo carinho, pela confiança, pelo apoio e por tudo que passamos juntas nesses três anos e meio de convivência.

Às amigas Cibele M. Prado e Érica C. Campos, pelos ensinamentos durante meus experimentos, por me auxiliarem nas dificuldades, e principalmente, pela amizade verdadeira, pelas longas conversas, por muitos momentos de aprendizado.

Às minhas amigas de laboratório, Karina M. A. Mata, pela amizade, por estarmos juntas desde o início do mestrado amadurecendo e vencendo as dificuldades, e Marcela S. Oliveira, pela amizade, companheirismo, carinho, pelas longas conversas e pela "troca de personalidade".

À amiga e companheira Anelise B. Assalin por auxiliar durante meus experimentos e pela disponibilidade em ajudar sempre, e acima de tudo, pela amizade sincera, pelo amor, carinho e pelo precioso apoio em todos os momentos.

Aos amigos do laboratório de Patologia Pulmonar, Paula Prudente e Fábio S. Rocha, na troca de experiências profissionais, pelo carinho e amizade.

Aos amigos do Departamento de Patologia, Tassiana Marini, Cleverson R. Fernandes, Andiara De Rossi, Gisele Faria, Lenaldo Branco Rocha, Valdecir Blefari, Luciana S. Amâncio, agradeço pelo carinho e pelos momentos de descontração.

Ao funcionário do biotério Paulo Henrique da Silva, pelo cuidado e dedicação no manuseio dos animais e pelo auxílio no tratamento dos animais durante meu experimento.

Aos funcionários do Departamento de Patologia Toninho e Daniel pela assistência dispensada quando solicitado.

Às funcionárias da limpeza Rose, Karina, Vanessa, Diraci, Beatriz (Bia), pela manutenção diária de nosso laboratório e pela simpatia dispensada a todas as pessoas.

Aos meus colegas pós-graduandos do Departamento de Patologia, agradeço pela harmoniosa convivência. 


\section{À toda minha família de Franca e Ribeirão Preto}

A vocês que me deram um precioso apoio e torceram para que eu pudesse continuar nesse caminho e realizasse meu objetivo.

À minha avó Augusta C. Ferreira e minha tia Marilza F. A Franco e família, pelas constantes orações e torcida pelo meu melhor.

À minha querida prima Roberta K. Terra, um anjo um pouco rebelde, que Deus colocou no meu caminho para cuidar de mim na ausência dos meus pais. Obrigada pelo amor, carinho e dedicação.

Ao Rodrigo T. Figueiredo, que me apoiou desde o início do meu mestrado, incentivando-me a nunca desistir dos meus objetivos.

Aos amigos de Franca, Ana Maria S. Abib, Ana Paula Rodrigues, Ana Elise dos Santos, Daniela Mendonça, Denise C. Pereira, Fernanda P. Paula, José Fernando Pereira, Airton Moisés, Gisele Nascimento, Vanessa Borini, e ao pequeno Estevão, que mesmo estando longe, caminharam comigo e sempre torceram pela concretização desse objetivo. "Mesmo se um dia distante estivermos, unidos estaremos".

Às minhas queridas ex-companheiras de república, Paula C. Rugani e Viviane T. Silva, pelo carinho e pelo apoio, e sei que a distância se faz pequena a tanta cumplicidade.

Ao Juliano F. Santos, pelo carinho, pela compreensão e incentivo durante a finalização deste trabalho.

Agradeço a todos que contribuíram direta ou indiretamente para realização desse trabalho!!!

"Deus nos concede a cada dia, uma página de vida nova no livro do tempo. Aquilo que colocarmos nela, corre por nossa conta" 
"O aumento do conhecimento é como uma esfera dilatando-se no espaço: quanto maior a nossa compreensão, maior o nosso contato com o desconhecido". 


\section{RESUMO}

TEFÉ-SILVA, C. Interferência da Dexametasona no Ciclo Pulmonar da infecção por Strongyloides venezuelensis em Ratos Wistar. 2008. $107 \mathrm{f}$. Dissertação (Mestrado). Departamento de Patologia - Faculdade de Medicina de Ribeirão Preto, Universidade de São Paulo, 2008.

As estrongiloidíases são parasitoses intestinais causadas por várias espécies do gênero Strongyloides e apresentam distribuição cosmopolita. O objetivo deste estudo foi investigar a interferência do tratamento diário com dexametasona no ciclo pulmonar durante a infecção por Strongyloides venezuelensis em ratos. Investigamos o efeito do tratamento com glicocorticóides na migração de eosinófilos, mastócitos e macrófagos no parênquima pulmonar. Demonstramos ainda, como os efeitos do tratamento diário com a dexametasona atuam na formação do granulomas. Três principais aspectos foram encontrados: 1) Aumento da inflamação hemorrágica, provocado pela passagem das larvas para o espaço alveolar; 2) Significante redução da migração de eosinófilos e mastócitos no eixo axial pulmonar e, 3) Interferência crucial na migração de eosinófilos para os focos de passagem das larvas e, conseqüente, impedimento da organização do granuloma, sugerindo que a formação da rede de fibras reticulares deve ter um papel crucial no aprisionamento do parasita, favorecendo um melhor desempenho das células inflamatórias na eliminação do mesmo. Este trabalho mostrou que o uso de drogas com ação imuno-modulatória, tais como a dexametasona, pode interferir na morbidade no ciclo pulmonar durante a infecção por $S$. venezuelensis, contribuindo para revelar os mecanismos envolvidos na sua patogênese.

Palavras-chave: Strongyloides venezuelensis, parasitas, pulmão, dexametasona. 


\begin{abstract}
TEFÉ-SILVA, C. Interference of dexamethasone in pulmonary cycle of infection by Strongyloides venezuelensis in Wistar rats. $2008.107 f$. Dissertação (Mestrado). Departamento de Patologia - Faculdade de Medicina de Ribeirão Preto, Universidade de São Paulo, 2008.

The aim of this study was investigate the interference of dexamethasone treatment in the pulmonary cycle of Strongyloides venezuelensis infection in rats. The immunomodulatory effects on the inflammatory process generated by the passage of the larvae into pulmonary parenchyma during their migration were analyzed. Three principal effects were found: 1) Increased alveolar hemorrhagic inflammation provoked by the passage of larvae into the alveolar spaces; 2) Significant decrease of eosinophil and mast cell migration to the axial septum of the lungs and 3 ) Impaired eosinophil migration to the parasite foci and deficient formation of the reticular fiber network, interfering with the granuloma organization. This study demonstrated that the use of drugs with immunomodulatory actions, such as dexamethasone, in addition to interfere with the morbidity from the pulmonary cycle of $S$. venezuelensis infection, can contribute to reveal the mechanisms involved in its pathogenesis.
\end{abstract}

Keywords: Strongyloides venezuelensis, parasites, lung, dexamethasone. 


\section{LISTA DE ILUSTRAÇÕES}

Figura 1. Evolução do peso corporal dos animais.

Figura 2. Aspectos macro e microscópicos dos pulmões de ratos infectados com $S$. venezuelensis e tratados com dexametasona após 1 dia de infecção.

Figura 3. Aspectos macro e microscópicos dos pulmões de ratos infectados com S. venezuelensis e tratados com dexametasona após 3 dias de infecção.

Figura 4. Aspectos macro e microscópicos dos pulmões de ratos infectados com S. venezuelensis e tratados com dexametasona após 5 dias de infecção.

Figura 5. Aspectos macro e microscópicos dos pulmões de ratos infectados com S. venezuelensis e tratados com dexametasona após 7 dias de infecção.

Figura 6. Aspectos macro e microscópicos dos pulmões de ratos infectados com S. venezuelensis e tratados com dexametasona após 14 dias de infecção.

Figura 7. Aspectos macro e microscópicos dos pulmões de ratos infectados com S. venezuelensis e tratados com dexametasona após 21 dias de infecção.

Figura 8. Distribuição dos mastócitos no eixo axial.

Figura 9. Fotomicrografia dos mastócitos no eixo axial.

Figura 10. Distribuição dos eosinófilos no eixo axial.

Figura 11. Fotomicrografia dos eosinófilos no eixo axial.

Figura 12. Distribuição dos eosinófilos no parênquima alveolar.

Figura 13. Distribuição dos macrófagos no parênquima alveolar.

Figura 14. Densitometria das fibras reticulares no parênquima alveolar.

Figura 15. Detalhe dos granulomas visualizados no parênquima alveolar dos animais infectados.

Figura 16. Detalhe dos aglomerados inflamatórios visualizados no parênquima alveolar dos animais infectados e tratados com dexametasona. 


\section{LISTA DE ABREVIATURAS}

\begin{tabular}{|l|l|}
\hline AIDS & Síndrome de Imunodeficiência Adquirida \\
\hline AP-1 & Proteína Ativadora 1 \\
\hline BSA & Soro Albumina Bovina \\
\hline C & Grupo Controle \\
\hline CD & Grupo Controle + Dexametasona \\
\hline CD68 & Anticorpo Específico para Macrófago \\
\hline DAB & Diaminobenzidina \\
\hline Dexa & Dexametasona \\
\hline F $R$ RI & Receptores de Superfície \\
\hline Fig. & Figura \\
\hline FGF & Fator de Crescimento Fibroblástico \\
\hline GCs & Glicocorticóides \\
\hline GM-CSF & Granulócitos-Monócitos, Fator Estimulante de Colônias \\
\hline HE & Hematoxilina-Eosina \\
\hline I & Grupo Infectado \\
\hline ID & Grupo Infectado + Dexametasona \\
\hline IFN- $\gamma$ & Interferon-gama \\
\hline Ig & Imunoglobulinas \\
\hline IL & Interleucina IL-1, IL-2, IL-3, IL-4, IL-5, IL-8, IL-9, IL-12... \\
\hline L-3 & Larva Filarióide Infectante \\
\hline LTh & Linfócitos T Auxiliares \\
\hline MCP & Proteína Quimiotática de Macrófago \\
\hline MIP & Proteína Inflamatória de Macrófago \\
\hline MMP-9 & Metaloproteinase-9 \\
\hline NF-kB & Fator Nuclear kB \\
\hline PBS & Tampão Salina Fosfato \\
\hline PFA & Paraformaldeído \\
\hline RANTES & Quimiocina Secretada e Expressa por Células T Normais \\
\hline S.c. & Subcutâneo \\
\hline SCF & Stem Cell Factor \\
\hline S.v & Strongyloides venezuelensis \\
\hline TIMP-1 & Inibidores de Metaloproteinase Teciduais Específicos-1 \\
\hline TGF- $\alpha$ & Fator de Crescimento e Transformação alfa \\
\hline TGF- $\beta 1$ & Fator de Crescimento e Transformaça beta \\
\hline TNF- $\alpha$ & Fator de Necrose Tumoral alfa \\
\hline VEGF & Fator de Crescimento Vascular Endotelial \\
\hline & \\
\hline
\end{tabular}




\section{SUMÁRIO}

1 INTRODUÇÃO 20

1.1 AGENTE ETIOLÓGICO 20

1.2 RELAÇÃO PARASITA-HOSPEDEIRO 23

1.3 EOSINÓFILOS 24

1.4 MASTÓCITOS 25

1.5 ESTRONGILOIDÍASES X DESORDENS ALÉRGICAS 26

1.6 GLICOCORTICÓIDES 27

2 JUSTIFICATIVA E OBJETIVOS 29

3 MATERIAIS E MÉTODOS 31

3.1 ANIMAIS 32

3.2. MANUTENÇÃO DOS PARASITAS 32

3.3 DELINEAMENTO EXPERIMENTAL 33

3.4 PESO DOS ANIMAIS 34

3.5 EUTANÁSIA DOS ANIMAIS 34

3.6 MICROSCOPIA ÓPTICA CONVENCIONAL 34

3.7 ANÁLISE IMUNOISTOQUÍMICA 35

3.8 ANÁLISE ESTEREOLÓGICA 36

3.9 ANÁLISE MORFOMÉTRICA 37

3.9.1 INFILTRADO EOSINOFÍLICO (EIXO AXIAL) 37

3.9.2 INFILTRADO EOSINOFÍLICO (PARÊNQUIMA ALVEOLAR) 37

3.9.3 MASTÓCITOS (EIXO AXIAL) 38

3.9.4 FIBRAS RETICULARES 38

3.10 ANÁLISE ESTATÍSTICA 39

4 RESULTADOS 40

4.1 ESTADO GERAL DOS ANIMAIS 41

4.2 ANÁLISE MORFOLÓGICA DO PULMÃO 42

4.3 ANÁLISE QUANTITATIVA DE MASTÓCITOS NO EIXO AXIAL 54

4.4 ANÁLISE QUANTITATIVA DO INFILTRADO EOSINOFÍLICO NO EIXO AXIAL

4.5 ANÁLISE QUANTITATIVA DO INFILTRADO EOSINOFÍLICO

NO PARÊNQUIMA ALVEOLAR 
4.6 ANÁLISE QUANTITATIVA DE MACRÓFAGOS NO PARÊNQUIMA ALVEOLAR POR ESTEREOLOGIA 60

4.7 ANÁLISE DA PRESENÇA DE FIBRAS RETICULARES 62

5 DISCUSSÃO 66

5.1 ESTADO GERAL DOS ANIMAIS 67

5.2 INFLAMAÇÃO HEMORRÁGICA ALVEOLAR 68

5.2 MIGRAÇÃO DE EOSINÓFILOS E MASTÓCITOS 70

5.3 FORMAÇÃO DO GRANULOMA 72

6 CONCLUSÕES 76

REFERÊNCIAS 78

$\begin{array}{ll}\text { ANEXOS } & 86\end{array}$ 


\section{INTRODUÇÃO}

As estrongiloidíases são parasitoses intestinais causadas por nematódeos do gênero Strongyloides que acometem mamíferos, principalmente o homem, mas podem ser encontradas em outras espécies, tais como: aves, répteis e anfíbios (VINEY; LOK, 2007). Embora tenha sido descoberta há mais de cem anos, ainda há muito a ser esclarecido sobre esta parasitose. No gênero Strongyloides estão incluídas 52 espécies, das quais, duas têm importância em saúde pública por causar infecção no homem: Strongyloides stercoralis e Strongyloides fuelleborni. Outras espécies, tais como Strongyloides venezuelensis e Strongyloides ratti são muito utilizadas como modelos experimentais em ratos e camundongos para estudo da infecção humana, bem como para a biologia do seu agente causador (TAKAMURE, 1995; GROVE, 1996). Estudos mostraram durante a infecção pelo Strongyloides venezuelensis, a migração das larvas através do pulmão antes de se estabelecerem na mucosa intestinal do hospedeiro similar à migração do Strongyloides stercoralis em humanos (FERREIRA et al.,2007)

As estrongiloidíases têm distribuição mundial, mas ocorrem principalmente em regiões tropicais, onde condições ambientais, tais como, umidade relativa do ar alta, temperaturas elevadas e solos ricos em matéria orgânica bem oxigenada, favorecem o desenvolvimento do parasita. Sua prevalência é alta em países da África, Ásia e América do Sul, particularmente no Brasil e na Colômbia (CARVALHO; PORTO, 2004; MATSUDA et al., 2007). 


\subsection{AGENTE ETIOLÓGICO}

O Strongyloides sp é o menor dos nematódeos e apresenta uma peculiaridade interessante: a única forma parasitária adulta presente no intestino delgado é a fêmea partenogenética, que se reproduz dentro do hospedeiro sem a presença do macho, liberando seus ovos no duodeno (GROVE, 1994; MELO, 1995).

O Strongyloides sp tem um complexo ciclo de vida com aspectos morfológicos que variam de acordo com as diversas formas evolutivas existentes durante seu ciclo. As fêmeas partenogenéticas triplóides (3n), se instalam na mucosa intestinal e liberam de 30 a 40 ovos por dia, produzindo simultaneamente, três tipos de ovos que originam as larvas rabditóides, são encontradas nas fezes ou em fluidos intestinais. As larvas rabditóides: podem ser triplóides (3n), diplóides (2n) ou haplóides (1n), e são liberadas no interior do hospedeiro. A larvas filarióides: triplóides (3n), originam-se a partir das larvas rabditóides. São as formas infectantes do parasita, sendo capazes de penetrar pela pele ou mucosas. As fêmeas diplóides (2n) e machos haplóides (1n) de vida livre: originados também a partir das larvas rabditóides (GROVE, 1996; COSTA-CRUZ, 2005).

Estas fases evolutivas podem se desenvolver em dois ciclos distintos. $O$ primeiro é o direto ou partenogenético, no qual as larvas rabditóides (3n) chegam ao meio externo levadas pelas fezes, onde transformam-se diretamente em larvas filarióides (3n) infectantes. O segundo ciclo é o indireto ou de vida livre, no qual as larvas rabditóides $(2 n)$ e $(1 n)$ transformam-se, respectivamente, em fêmeas e machos de vida livre, que por reprodução sexuada, originam larvas filarióides infectantes (3n) (GROVE, 1996). No hospedeiro, as larvas infectantes penetram de forma ativa na pele íntegra ou ocasionalmente pelas mucosas, principalmente pela boca e esôfago quando são deglutidas através de alimentos contaminados. Essas 
larvas secretam proteases que auxiliam tanto na penetração quanto na migração através dos tecidos. Após a penetração, as larvas caem na circulação sangüínea, passam pelo ventrículo direito, chegam aos capilares pulmonares e atravessam a membrana alveolar, migrando pela árvore traqueo-brônquica até a faringe. Elas então, podem ser expelidas ou deglutidas, passando pelo esôfago, estômago e finalmente, ao chegarem na mucosa intestinal, sofrem transformação em fêmeas partenogenéticas. Este é o modo usual de transmissão chamada de hetero ou primoinfecção, que ocorre através da pele, mas há outros tipos de infecção, como auto-infecção e hiperinfecção (TAKAMURE, 1995; VINEY; LOK, 2007).

Um modo peculiar de infecção conhecida como auto-infecção que pode ser externa (larvas rabditóides na região perianal transformam-se em larvas filarióides) ou externa (larvas rabditóides, ainda na mucosa intestinal, transformam-se em larvas), as larvas caem na circulação e reiniciam o ciclo, aumentando assim a carga parasitária. A auto-infecção é responsável pela longa permanência do parasita no hospedeiro e o principal fator no desenvolvimento das formas graves da estrongiloidíase (CARVALHO; PORTO, 2004). O processo de auto-infecção pode sofrer uma exacerbação com aumento do número de larvas e fêmeas, chamado de hiperinfecção. que podem se disseminar por todo organismo (SCHAEFFER et al., 2003, VINEY; LOK, 2007).

Clinicamente, a estrongiloidíase pode se apresentar sob as formas aguda e crônica, podendo esta última ser assintomática, sintomática ou grave. Entretanto, a maioria dos indivíduos infectados são assintomáticos ou oligossintomáticos. As principais alterações na estrongiloidíase são devidas às ações mecânicas, traumáticas, irritativas, tóxicas e antigênicas, em decorrência das fêmeas partenogenéticas, das larvas ou dos ovos. Estas ações podem ser estudadas de 
acordo com a sua localização no hospedeiro, aparecendo em três fases: cutânea, pulmonar e intestinal. A fase cutânea em geral é discreta, caracterizada por leve hemorragia acompanhada de prurido, no local da penetração da larva. A migração das larvas pelo pulmão pode provocar tosse com ou sem expectoração, febre, dispnéia e crises asmatiformes em decorrência da presença das larvas filarióides. Os sintomas intestinais aparecem quando a fêmea partenogenética instala-se na mucosa, produzindo dor epigástrica, acompanhada de náuseas, vômitos, diarréias intermitentes e síndromes disentéricas (KEISER; NUTMAN, 2004; CONCHA; HARRINGTON JR; ROGERS, 2005).

A elevada prevalência em regiões tropicais e subtropicais, a facilidade de transmissão, o caráter de cronicidade e a auto-infecção, originam as formas graves de hiperinfecção e disseminação, podendo muitas vezes evoluir para óbito, tornando a estrongiloidíase um importante problema médico e social.

\subsection{RELAÇÃO PARASITA-HOSPEDEIRO}

A interação entre o Strongyloides sp e o hospedeiro é complexa, envolvendo diversos fatores, dentre eles, a resposta imunológica elicitada pelo hospedeiro, a fertilidade das fêmeas e os mecanismos de evasão do parasita, entretanto, esses fatores ainda não estão bem esclarecidos. Existem evidências mostrando que tanto a resposta imune celular como a humoral contribuem para a resolução da estrongiloidíase (KORENAGA et al., 1994; GROVE,1996).

Estudos prévios envolvendo a resposta imunológica humoral têm demonstrado que camundongos infectados por $S$. stercoralis apresentam imunidade humoral mediada pelas imunoglobulinas IgA, IgE, IgG e IgM (ABRAHAN et al., 1995). O aumento de $\lg E$ estaria associado à intensa eosinofilia gerada pela presença das 
larvas (DUTCHER et al., 1990), entretanto, a regulação da resposta humoral na estrongiloidíase ainda merece investigações mais detalhadas (ATKINS et al., 1997). Além da resposta humoral, pode ocorrer também a resposta imune celular com a participação efetiva principalmente de eosinófilos e mastócitos.

\subsection{EOSINÓFILOS}

A resposta imunológica é geralmente similar nas infecções helmínticas, caracterizada pela resposta $\mathrm{T}$ - dependentes com perfil Th2, correspondendo à células que secretam interleucinas como IL-4 e IL-5. A IL-4 estimula a produção de anticorpos lgE específicos para helmintos que opsonizam esses parasitas. A IL-5 ativa eosinófilos que se ligam aos helmintos revestidos de $\lg E$ através de receptores. Os eosinófilos são importantes células efetoras, tanto nas infecções helmínticas quanto nas doenças atópicas como asma e rinite alérgica. Nesses casos, ocorre sua produção e diferenciação na medula óssea, quimiotaxia, acúmulo no sangue e no tecido, além da sua ativação local, sendo abundantes em infiltrados inflamatórios, especialmente quando acontecem no revestimento mucoso do trato respiratório e gastrointestinal. (MCLAREN; RAMALHO-PINTO; SMITHERS, 1978). Os eosinófilos ativados liberam citoplasmáticos que contêm proteína básica principal, proteína catiônica de eosinófilo, peroxidases, neurotoxinas que são capazes de destruir os tegumentos dos helmintos (ABBAS, LICHTMAN, 2005). Além da liberação de seus grânulos, os eosinófilos atuam mediando os processos inflamatórios através da síntese e produção de numerosas citocinas, quimiocinas, fatores de crescimento, na defesa contra infecção por parasitas (COFFMAN et al., 1989; DRUILHE; LÉTUVÉ; PRETOLANI, 2003). 
Estudos realizados em cobaias mostraram que a administração de IL-5 pode promover acúmulo de eosinófilos nos pulmões e também aumentar os efeitos quimioatrativos da eotaxina, uma quimiocina da família CC responsável pela migração seletiva dos eosinófilos para o local da inflamação (ROTHENBERG et al.,1996).

\subsection{MASTÓCITOS}

As infecções causadas pelos nematódeos gastrointestinais são acompanhadas também por mastocitose na tentativa de eliminação do parasita (ONAH; NAWA, 2000). Os mastócitos são derivados da medula óssea e amadurecem nos tecidos, localizando-se geralmente no interstício dos vasos sangüíneos e no tecido perineural logo abaixo do epitélio. Expressam receptores em sua superfície que ligam-se à $\lg E$, possuindo alta afinidade $\left(F_{c \varepsilon} R I\right)$ através de um processo de sensibilização. Essa sensibilização altera o estado funcional os mastócitos, além de ativar um mecanismo de amplificação da reação (YAMAGUCHI et al., 1997). A ligação cruzada de antígenos do parasita com moléculas de IgE presentes nas superfícies dos mastócitos, leva a desgranulação, ativação e secreção de uma série de mediadores pró-inflamatórios e citocinas.

Estudos com Toxocara canis têm descrito mastocitose pulmonar e intestinal, correlacionando os níveis de histamina nesses tecidos com a presença de mastócitos na resposta inflamatória induzida pelo helminto (PELLIZZON et al., 1994). No entanto, até o presente momento, o papel funcional dos mastócitos durante a expulsão dos nematódeos não está totalmente esclarecido. 


\subsection{ESTRONGILOIDÍASES X DESORDENS ALÉRGICAS}

O Strongyloides sp é um helminto essencialmente intestinal, mas faz parte do seu ciclo de vida, a passagem das larvas pelos pulmões antes de se estabelecerem definitivamente no duodeno. Os pulmões tornam-se assim, ao lado do trato gastrointestinal, fundamentais no entendimento dos mecanismos patogenéticos desta parasitose. Estudos têm demonstrado que a infestação por helmintos $e$ as desordens alérgicas, como a asma apresentam muitas características em comum. Tanto os componentes celulares, como mastócitos e eosinófilos, quanto os humorais como imunoglobulinas, citocinas e, possivelmente, quimiocinas estão presentes de forma muito semelhante em ambos os casos. Negrão-Correa et al. (2003) demonstraram inflamação eosinofílica peribrônquica, com aumento da produção de muco e $\lg E$, características semelhantes às observadas em pacientes asmáticos. Embora com diferenças fundamentais no tamanho dos agentes causadores das lesões, bem como na exacerbação da resposta inflamatória, muitas das alterações patológicas, imunológicas e funcionais observadas em asmáticos podem estar envolvidas nos mecanismo de resposta imunológica e celular contra parasitas com ciclo pulmonares. Por esses motivos, através de métodos comparativos, podemos considerar a asma como um modelo para estudo, considerando que os aspectos anátomo-patológicos das doenças alérgicas ainda não estão completamente definidos e menos ainda se sabe sobre as conseqüências da passagem das larvas pelos capilares pulmonares nas infecções por nematódeos. 


\subsection{GLICOCORTICÓIDES}

Os glicocorticóides são esteróides antiinflamatórios produzidos na zona fasciculada do córtex da adrenal. Como são moléculas lipossolúveis, difundem-se facilmente através das membranas celulares. Exercem seus efeitos pela ligação aos receptores que se encontram no citoplasma, então o complexo é translocado para o núcleo, ligando-se em genes alvos inibindo a transcrição de vários genes para citocinas, enzimas, receptores e moléculas de adesão (NEWTON, 2000; LIBERMAN et al., 2007).

A dexametasona é um glicocorticóide que possui um amplo espectro de ação sendo um potente antiinflamatório e imunossupressor uma vez que ela age sobre vasos sangüíneos, diversos mediadores, precursores e tipos celulares inflamatórios e tem atividade marcante sobre o sistema imunológico. Tem um efeito sobre a concentração, a distribuição e a função dos leucócitos periféricos, bem como efeitos supressores sobre a produção de citocinas e de outros mediadores lipídicos e glicolipídicos da inflamação (ROBERT et al., 1995; PARFITT et al., 1999). Como conseqüência da inibição de fatores de transcrição como o NF-kB e da AP-1, há ainda inibição da síntese das citocinas IL-1, IL-2, IL-3, IL-4, IL-5, IL-6, IL-11, IL-12, IL-13, das quimiocinas de IL-8, RANTES, MCP-1, MCP-3, MCP-4, MIP-1 $\alpha$ e eotaxina (BARNES, 1998).

Com relação às infecções helmínticas, os glicocorticóides atuam inibindo a ativação, proliferação e sobrevivência de células inflamatórias, como eosinófilos e mastócitos através do bloqueio das citocinas IL-4, IL-5 e IL-13, responsáveis pelo recrutamento e sobrevivência destas células (BARNES, 1998). Estudos mostraram que os glicocorticóides, além de inibir a ação do IL-5 na sobrevivência dos eosinófilos, também podem atuar como inibidores da proteína básica principal 
presentes nos eosinófilos (WALLEN et al., 1991). Com relação aos mastócitos, pouco se sabe sobre os efeitos dos glicocorticóides sobre essas células, mas acredita-se que os glicocorticóides também inibem a síntese de citocinas e fatores de crescimento responsáveis pela ativação dos mastócitos (COHAN et al., 1989; BARNES, 1998).

Diversos autores mostraram casos de hiperinfecção e disseminação de $S$. stercoralis em pacientes recebendo tratamento com corticosteróides. Uma explicação para esta habilidade de induzir a hiperinfecção estaria na supressão da ativação de eosinófilos e linfócitos. Estudos têm sugerido que os glicocorticóides também poderiam atuar diretamente sobre o parasita, interferindo no metabolismo dos seus hormônios esteróides e sinalizando para um aumento da fertilidade das fêmeas parasitas, que passariam a produzir grande quantidade de ovos. Esses ovos ainda na mucosa intestinal poderiam originar larvas infectantes, que se disseminariam por todo organismo (GENTA, 1992; KEISER; NUTMAN, 2004; FARDET et al., 2007). 


\section{JUSTIFICATIVA E OBJETIVOS}

Há uma estimativa que 100 milhões de pessoas são infectadas pelo Strongyloides stercoralis em todo mundo. Os efeitos da imunossupressão nas parasitoses vêm adquirindo cada vez mais importância, devido à disseminação do agente em indivíduos imunossuprimidos, tais como: infectados pelo vírus HIV, transplantados, com consumo excessivo de bebidas alcoólicas, nas doenças autoimunes, pela desnutrição, ou ainda, pelo uso freqüente de glicocorticóides. Nestes indivíduos pode ocorrer a disseminação do $S$. stercoralis, fato esse que se não diagnosticado e tratado precocemente, pode levar o paciente a óbito. O processo inflamatório gerado durante a infecção é essencial para a resposta contra o parasita, por isso, a compreensão desse processo permitirá esclarecer os mecanismos responsáveis pelo controle do parasita e do dano tecidual associado ao processo inflamatório durante a estrongiloidíase, bem como os efeitos da imunossupressão no hospedeiro infectado.

Os objetivos do presente estudo foram:

- Identificar as alterações morfológicas que ocorrem no parênquima pulmonar pela passagem das larvas nos septos alveolares em decorrência da infecção experimental pelo Strongyloides venezuelensis em ratos Wistar e os efeitos do tratamento diário com o glicocorticóide dexametasona, sobre estas alterações;

- Identificar as células envolvidas no processo inflamatório desenvolvido no parênquima pulmonar durante a passagem das larvas pelos septos alveolares e a interferência do tratamento diário com o glicocorticóide dexametasona, sobre estas células e, 
- Analisar os efeitos da imuno-modulação da resposta inflamatória durante a passagem das larvas do parasita, em decorrência do uso crônico do glicocorticóide dexametasona, durante 21 dias de infecção pelo Strongyloides venezuelensis em ratos Wistar. 


\section{MATERIAIS E MÉTODOS}

\subsection{ANIMAIS}

Foram utilizados ratos Wistar (Rattus novergicus) SPF (Specific Pathogen Free) pesando entre 100 a $120 \mathrm{~g}$, provenientes do biotério da Universidade Estadual de Campinas (UNICAMP). Os animais foram mantidos no biotério do Departamento de Patologia e tiveram livre acesso à água e alimento, com o cuidado de utilizar maravalha previamente autoclavada. Os procedimentos adotados nos experimentos foram aprovados pela Comissão de Ética em Experimentação Animal (CETEA) protocolo n9170/2007.

\subsection{MANUTENÇÃO DOS PARASITAS}

O nematódeo Strongyloides venezuelensis foi isolado do roedor Bolomys lasiuris e mantido no Departamento de Parasitologia da UNICAMP. Para a manutenção da linhagem L-2 do Strongyloides venezuelensis foram utilizados ratos infectados com 9.000 larvas, via subcutânea da linhagem L-3 de Strongyloides venezuelensis. No sétimo dia após infecção, foram colhidas as fezes para a realização de culturas. As fezes foram cultivadas em carvão mineral por dois dias em estufa a $2^{\circ} \mathrm{C}$ para obtenção das larvas filarióides (L3). As larvas L3 foram recuperadas do carvão utilizando método de Rugai (RUGAI; MATTOS; BRISOLA, 1954). Após a quantificação das larvas, novos ratos foram inoculados com 9.000 larvas L-3. 


\subsection{DELINEAMENTO EXPERIMENTAL}

Os animais foram divididos em quatro grupos, descritos a seguir:

- $\quad$ Controle/Salina (C)

- $\quad$ Controle/Tratado com Dexametasona (CD)

- Infectado/Salina (I)

- Infectado/Tratado com Dexametasona (ID)

A eutanásia foi realizada nos dias 1, 3, 5, 7, 14 e 21 .

INFECÇÃO DOS RATOS

Os grupos (I) e (ID) foram inoculados subcutaneamente com 9.000 larvas infectantes (L3) de Strongyloides venezuelensis em $300 \mu$ de PBS (Tampão salina fosfato) na região abdominal. Os grupos controles (C) e (CD) foram inoculados com $300 \mu \mathrm{l}$ de PBS.

\section{TRATAMENTO DOS ANIMAIS COM DEXAMETASONA}

Os grupos (CD) e (ID) foram tratados com glicocorticóide comercial (Decadron® - fosfato dissódico de dexametasona) na dose de $2 \mathrm{mg} / \mathrm{kg}$ administrado via subcutânea. A primeira dose foi administrada 1 hora antes da infecção e depois, diariamente, até o $21^{\circ}$ dia após a infecção, sendo a última dose administrada 1 hora antes da morte dos animais. 


\subsection{PESO DOS ANIMAIS}

Os ratos tiveram as caudas marcadas e seus pesos anotados por várias vezes (quatro vezes por semana), para avaliação de perda ponderal provocada pela infecção e/ou tratamento.

\subsection{EUTANÁSIA DOS ANIMAIS}

Os animais, depois de pesados, foram anestesiados com associação de cloridrato de cetamina $(74 \mathrm{mg} / \mathrm{kg})$ e xilazina $(8 \mathrm{mg} / \mathrm{kg})$, via intra-muscular, imobilizados em decúbito dorsal numa mesa cirúrgica adaptada. Através de incisão cirúrgica mediana iniciando na região do abdômen até a região frontal do pescoço, os planos foram dissecados. Em seguida, a caixa torácica foi aberta expondo o coração ainda pulsando e a traquéia dissecada e isolada, com auxilio de fio cirúrgico. Foi realizada então uma incisão na região frontal, onde foi inserida uma cânula (PE20) para perfusão de $3 \mathrm{ml}$ de fixador. $\mathrm{O}$ fixador utilizado foi $\mathrm{o}$ paraformaldeído (PFA) a 4\% diluído em PBS. Após a perfusão, a traquéia foi fechada com fio cirúrgico, os pulmões retirados e imersos no fixador previamente citado.

\subsection{MICROSCOPIA ÓPTICA CONVENCIONAL}

Os fragmentos foram processados como descrito a seguir: desidratação em séries crescentes de álcool 80, 90, 95 e 100\%, diafanização com xilol, infiltração e inclusão em parafina. A partir dos blocos, foram feitos cortes histológicos com $4 \mu \mathrm{m}$ de espessura em micrótomo automático (Leica RM 2155, Leica Microsystems Nussloch Gmbh, Nussloch, Alemanha). Os cortes foram dispostos em lâminas silanizadas e levados à estufa a $60^{\circ} \mathrm{C}$ por aproximadamente 12 horas. 


\subsection{ANÁLISE IMUNOISTOQUÍMICA}

A caracterização dos macrófagos foi realizada por imunoistoquímica, utilizandose o anticorpo específico (CD68) através do método da imunoperoxidase por meio da avidina-biotina-peroxidase.

A reação de imunoistoquímica iniciou-se com a desparafinização em xilol e posterior recuperação antigênica com tripsina por 25 minutos. Logo em seguida, os cortes foram lavados em solução PBS $0,01 \mathrm{M}(\mathrm{pH} 7,2)$. Todas as lavagens foram realizadas por três vezes consecutivas.

Posteriormente, seguiu-se o bloqueio da peroxidase endógena por meio da incubação dos cortes com água oxigenada a 3\% em PBS por 20 minutos. Após as lavagens com PBS, as lâminas foram incubadas com soro normal de cavalo diluído 1/50 por 30 minutos, a fim de se obter o bloqueio das ligações com proteínas inespecíficas. Em seguida, os cortes foram incubados com o anticorpo primário CD68 (clone ED-1, Serotec Ltda, London, UK) na diluição 1/100 em BSA, em câmara úmida, em uma temperatura de $4^{\circ} \mathrm{C}$ por uma noite.

Após esse período, várias lavagens consecutivas foram realizadas e, posteriormente, os cortes foram incubados à temperatura ambiente por 45 minutos com o anticorpo biotinilado: goat anti-mouse-lgG (Vector Laboratories, Burlingame, CA, USA). Depois de novas lavagens, os cortes foram incubados com o complexo avidina-biotina-peroxidase (Vector Laboratories, Burlingame, CA, USA) por 45 minutos, à temperatura ambiente.

Posteriormente ao procedimento acima citado, procedeu-se a revelação da reação utilizando-se o substrato revelador diaminobenzidina - DAB (Vector Laboratories, Burlingame, CA, USA) em PBS, contendo $0,1 \%$ de água oxigenada 
20 volumes, por 10 minutos, à temperatura ambiente. Finalmente, as reações foram interrompidas com água destilada e as lâminas contra-coradas com Hematoxilina de Harris por 45 segundos, à temperatura ambiente. Após coloração, as lâminas foram lavadas em água destilada, secas e montadas entre lâmina e lamínula com bálsamo do Canadá (Fisher Scientific). O controle negativo da reação foi realizado através da substituição do anticorpo primário por PBS.

\subsection{ANÁLISE ESTEREOLÓGICA}

A análise quantitativa de macrófagos foi realizada após a reação imunoistoquímica. A quantificação de macrófagos foi realizada utilizando análise estereológica em microscopia de luz. Estereologia corresponde a um conjunto de técnicas (de seção e análise de imagens) destinado à determinação de parâmetros tridimensionais de um órgão, tecido ou estrutura partindo-se do estudo de cortes bidimensionais (MANDARIM-DE-LACERDA, 2007). Para aplicação desse método, os corpos em estudo devem ser isotrópicos, ou seja, os diversos elementos que o compõem deviam estar distribuídos ao acaso e homogeneamente no espaço. Atualmente são utilizadas "grades" estereológicas, ou sistemas-teste, que facilitam o emprego dessa metodologia. As grades são figuras, geralmente retangulares, de área conhecida, contendo em seu interior um número predeterminado de pontos e segmentos de retas ou de arcos ciclóides, que podem ser sobrepostas às estruturas analisadas para a contagem de pontos e interseções das linhas que caem sobre o elemento em estudo. Em nosso trabalho, utilizamos um microscópio de luz acoplado a uma lente ocular com gratículo indexado de 100 pontos. Cada campo coberto pelo gratículo delimita uma área equivalente a $0.0625 \mathrm{~mm}^{2}$ no aumento de 400x. Os valores foram expressos em percentagens de pontos correspondentes que caíram sobre as células em 20 campos aleatórios não 
coincidentes (área total: $0.12 \mathrm{~mm}^{2}$ ). Os valores foram expressos em percentagem (\%).

\subsection{ANÁLISE MORFOMÉTRICA}

As imagens adquiridas a partir das lâminas de microscopia óptica convencional para eosinófilos, mastócitos e fibras reticulares foram analisadas morfometricamente com auxílio do programa Leica QWin® (Leica Microsystems Cambridge Ltda, Cambridge, Reino Unido), instalado em um microcomputador acoplado a uma câmara digital.

\subsubsection{Infiltrado eosinofílico (eixo axial)}

Eosinófilos corados por HE presentes no tecido peri-broncovascular (eixo axial) foram contados em 10 campos, escolhidos aleatoriamente em cada lâmina, com aumento de 400x (área total: $0.8 \mathrm{~mm}^{2}$ ). O resultado é expresso em número de células/área.

\subsubsection{Infiltrado eosinofílico (parênquima alveolar)}

Eosinófilos corados por HE presentes nos granulomas do parênquima alveolar foram contados em 10 campos no grupo I, com aumento de 400x (área total: 0.8 $\mathrm{mm}^{2}$ ). Nos demais grupos, 10 campos do parênquima alveolar, com ou sem aglomerados inflamatórios, foram escolhidos aleatoriamente em cada lâmina para serem analisados, $\mathrm{O}$ aumento foi de $400 \mathrm{x}$ e a área total de $0.8 \mathrm{~mm}^{2}$. O resultado é expresso em número de células/área. 


\subsubsection{Mastócitos (eixo axial)}

Mastócitos corados pelo método de Luna (LUNA, 1968) presentes no tecido peri-broncovascular (eixo axial) foram contados em 10 campos, escolhidos aleatoriamente em cada lâmina, com aumento de 400x (área total: $0.8 \mathrm{~mm}^{2}$ ). 0 resultado é expresso em número de células/área.

\subsubsection{Fibras Reticulares}

Para avaliação das fibras reticulares, as lâminas foram coradas com reticulina de Gomori (ROMEIS, 1948). Foram selecionados dez campos, escolhidos aleatoriamente em cada lâmina, para análise e quantificação das fibras. Através da análise de imagens, foram medidas as áreas ocupadas pelas fibras reticulares nos granulomas (grupo I) e nos septos alveolares (demais grupos). O sistema de análise utilizado é composto por um microscópio de luz acoplado à câmera de vídeo conectado a um computador. As imagens foram processadas, empregandose um programa de imagem Leica Qwin® software (Leica, Cambridge,UK). Este software permitiu delimitar a área a ser estudada através do estabelecimento prévio de padrões de cores, num espectro que vai do branco ao preto, passando por diversos tons de cinza, cria-se um padrão a partir do qual o computador reconhece o substrato em estudo e fornece a área ocupada por este. O padrão para fibras reticulares foi estabelecido individualmente para cada caso, colocandose o contraste a um nível em que as fibras eram reconhecidas facilmente como filamentos negros. A área ocupada pelas fibras foi determinada por densitometria digital e os resultados expressaram a quantidade de fibras reticulares (\%) por área 
total de $0.08 \mathrm{~mm}^{2}$. Brônquios e vasos foram cuidadosamente evitados durante as medidas.

\subsection{ANÁLISE ESTATÍSTICA}

Os resultados foram expressos em média \pm desvio padrão. As análises estatísticas foram realizadas pela análise de variância (ANOVA) e post hoc de Newman-Keuls para múltiplas comparações com auxílio do programa estatístico GraphPad Prism 4.0 (GraphPad Software Inc., San Diego, CA, EUA). Diferenças entre os resultados menores que $5 \%(P<0.05)$ foram consideradas significativas. 


\section{RESULTADOS}

\subsection{ESTADO GERAL DOS ANIMAIS}

Durante todo experimento não houve mortalidade nos diferentes grupos. Os grupos (C) e (I) apresentaram ganho de peso (145.6 \pm 24.7 e $178.6 \pm 45.5$, respectivamente). Contrariamente, os animais tratados com dexametasona (CD e ID) mostraram uma intensa perda de peso: $105.6 \pm 2.4$ e $101.3 \pm 1.2$, respectivamente $(P<0.001)$. Eles apresentaram letargia e piloereção, caquexia, com importante redução do tecido gorduroso subcutâneo. Os animais não apresentaram sinais de insuficiência respiratória durante todo o experimento (Fig. 1).

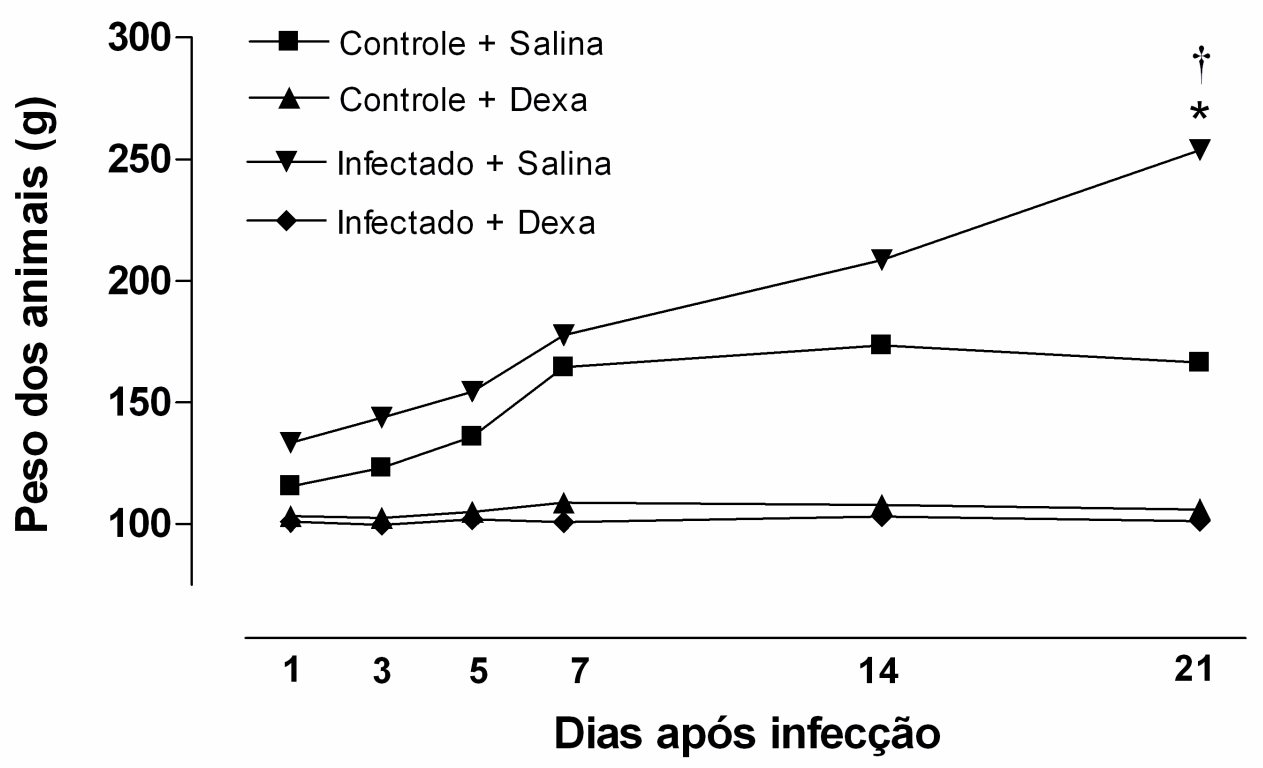

Figura 1. Evolução do peso corporal dos animais controles, infectados e/ou tratados com dexametasona. Os grupos tratados com dexametasona (CD) e (ID) apresentaram redução de peso significativa quando comparados aos grupos (C) e (I). O símbolo * representa a significância entre animais infectados e animais infectados e tratados, $\dagger$ representa animais infectados em relação ao controle $(P<0.05)$. Os resultados são expressos como média \pm SD (n: 6/dia/grupo). 


\subsection{ANÁLISE MORFOLÓGICA DO PULMÃO (ACHADOS MACROSCÓPICOS E MICROSCÓPICOS)}

\section{1ำ dia pós-infecção}

No primeiro dia pós-infecção, o parênquima pulmonar dos animais do grupo infectado apresentava arquitetura preservada, com pequenos e escassos focos hemorrágicos, chamando atenção a presença de larvas infectantes (L3) nos espaços alveolares. Esse processo estava acompanhado por infiltrado eosinofílico no interstício do eixo axial (tecido peri-broncovascular) e aumento dos macrófagos alveolares residentes.

Os animais infectados e tratados com a dexametasona apresentaram achados semelhantes no parênquima pulmonar, embora menos proeminentes em todos os aspectos, incluindo o infiltrado inflamatório (Fig. 2).

Os grupos-controles ( $C$ e $\quad C D$ ) não mostraram alterações relevantes no parênquima pulmonar. 


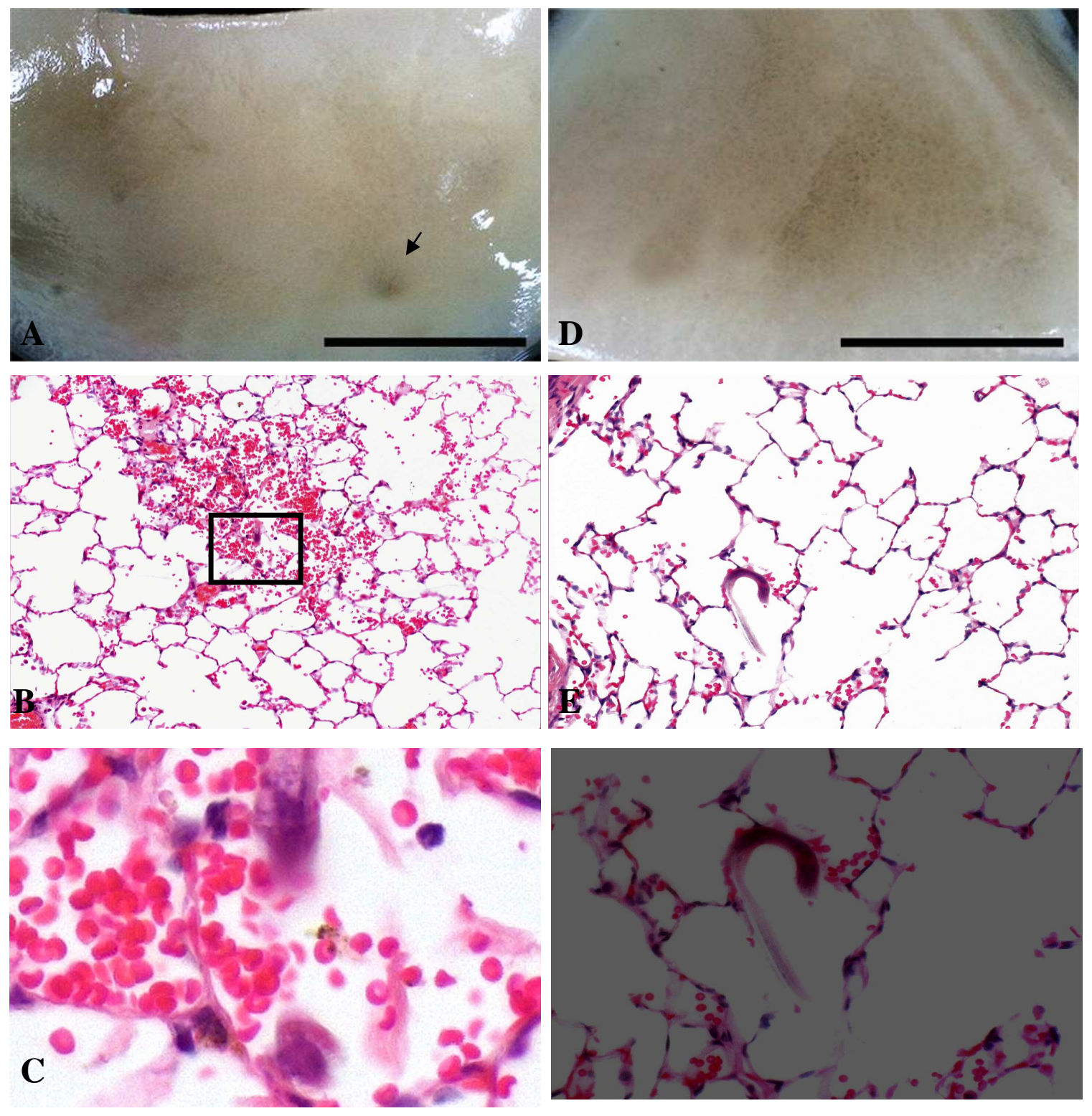

Figura 2. Aspectos macro e microscópicos dos pulmões de ratos infectados com $S$. venezuelensis (esquerda) e tratados com dexametasona (direita), após 1 dia de infecção. A Macroscopia mostrando escassos focos hemorrágicos na superfície pleural (seta); B Foco hemorrágico contendo larvas de permeio; C: Detalhe das larvas; D: Macroscopia sem grandes alterações na superfície pleural; E: Hemorragia alveolar mínima com presença de larvas livres no espaço alveolar; F: Detalhe da larva. Aumentos originais: 200x (A, B, D e E), 640x (C), 400x (F). Coloração HE. Barra: 4mm. 


\section{3ำ dia pós-infecção}

Nesse dia, as áreas hemorrágicas estavam multiplicadas, facilmente visualizadas na superfície pleural dos pulmões infectados. Microscopicamente, essas áreas correspondiam a hemorragias alveolares contendo larvas e cutículas fragmentadas, exsudato protéico intra-alveolar e células inflamatórias, especialmente macrófagos intra-alveolares. Houve aumento da quantidade de eosinófilos no eixo peri-broncovascular.

O grupo tratado mostrava hemorragias confluentes, maior número de larvas e cutículas fragmentadas. O infiltrado inflamatório era semelhante, embora menos proeminente, contendo eosinófilos estritamente no interstício peri-broncovascular (Fig. 3).

Os grupos-controles ( $C$ e $C D$ ) não mostraram alterações relevantes no parênquima pulmonar. 

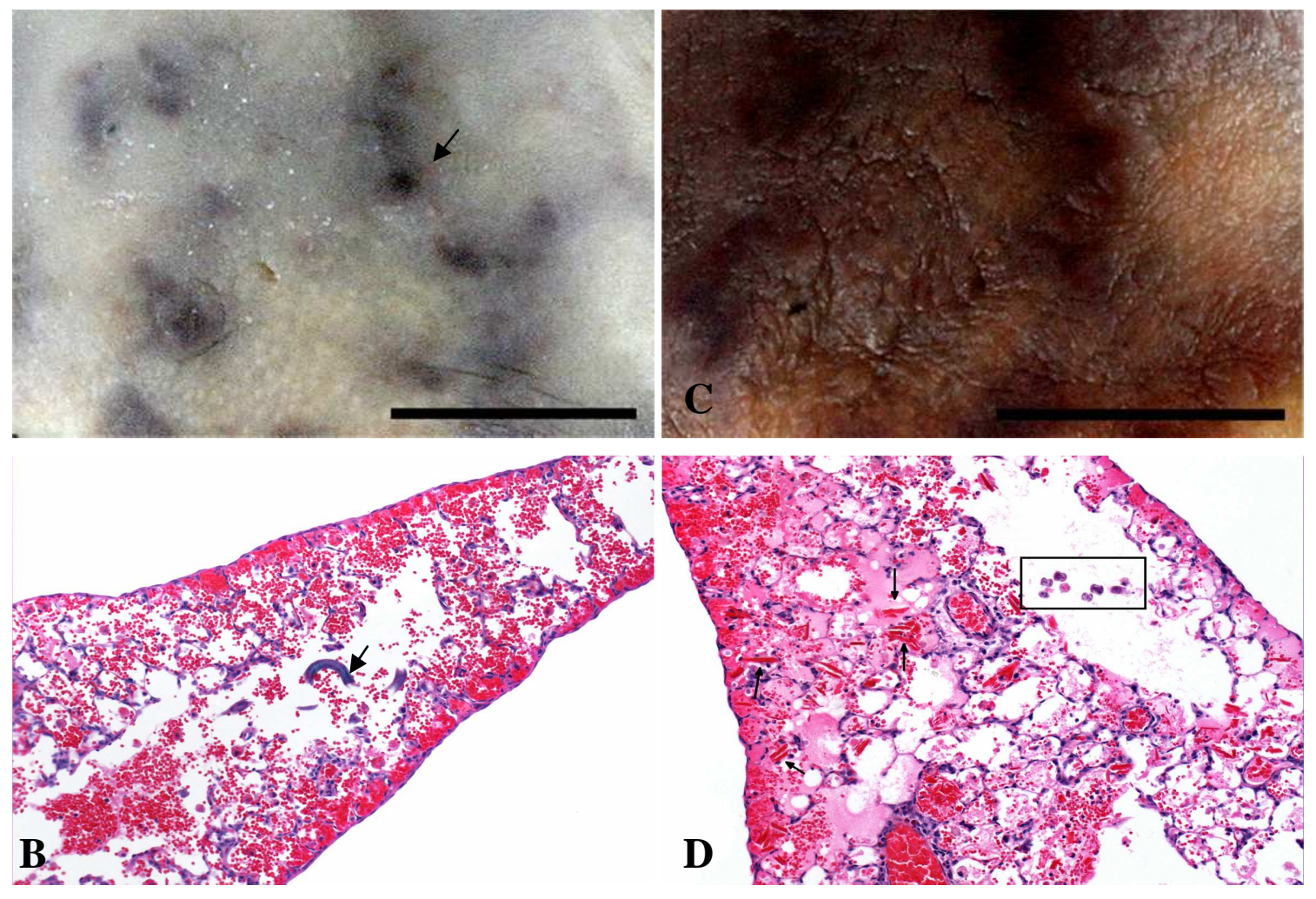

Figura 3. Aspectos macro e microscópicos de pulmões de ratos infectados com $S$. venezuelensis (esquerda) e tratados com dexametasona (direita) após 3 dias de infecção. A Macroscopia mostrando focos hemorrágicos na superfície pleural (seta); B: focos hemorrágicos proeminentes mostrando exsudato intra-alveolar e presença de larvas (seta); C: Macroscopia do pulmão com presença de focos hemorrágicos difusos por todo órgão; D: exsudato intra-alveolar e presença de larvas (detalhe) e fragmentos de cutículas (seta). Aumentos originais: 200x. Coloração HE. Barra: 4mm. 


\section{5ํ dia pós-infecção}

No $5^{\circ}$ dia, os focos hemorrágicos diminuíram signifi cativamente. Os macrófagos mostravam-se abundantes, dispersos nos espaços alveolares, alguns com aspecto xantomatoso ou contendo hemossiderina. Alguns começavam a se organizar formando granulomas. Estes granulomas eram constituídos por macrófagos e eosinófilos, algumas vezes células gigantes e o agente etiológico na porção central. Com a impregnação pela prata (coloração de Reticulina de Gomori), visualizamos o início de uma trama de fibras reticulares entre as células inflamatórias dos granulomas. O infiltrado eosinofílico diminuiu no eixo axial.

O grupo tratado, ao contrário, mostrou mais focos hemorrágicos distribuídos de forma difusa por todo órgão. Além de hemácias, o espaço alveolar continha grande quantidade de fibrina e cutículas fragmentadas de parasitas. O infiltrado inflamatório eosinofílico diminuiu quando comparado ao terceiro dia e se restringiu ao interstício perivascular e peribrônquico. Não houve evidências de formação de granuloma, embora tenha havido aumento no número de macrófagos xantomatosos e/ou com hemossiderina, distribuídos pelos espaços alveolares. A impregnação pela prata (coloração) não evidenciou aglomerado de fibras reticulares entremeando as células inflamatórias. Parasitas também não foram visualizados nas amostras examinadas (Fig. 4).

Os grupos-controles ( $C$ e $C D$ ) não mostraram alterações relevantes no parênquima pulmonar. 

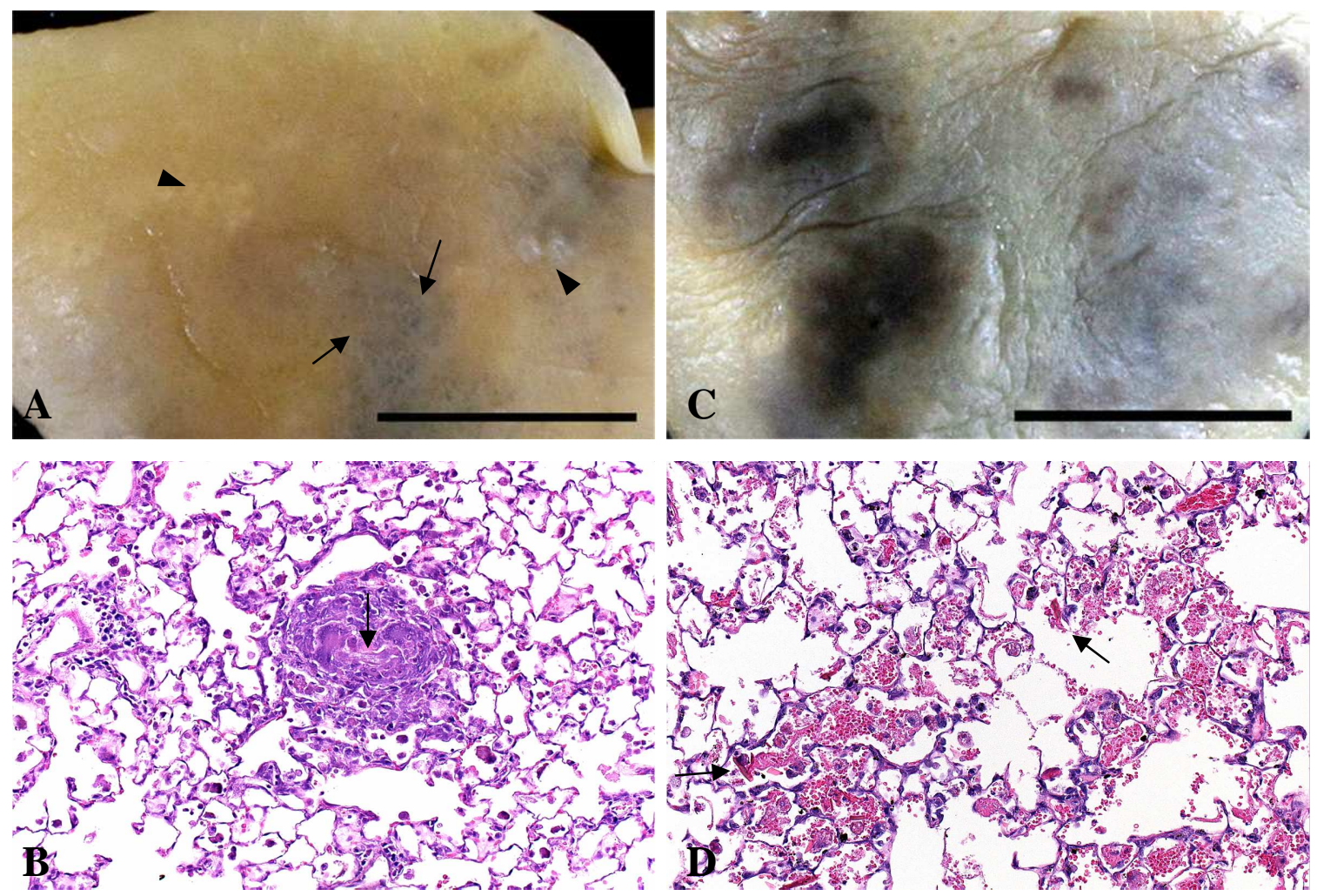

Figura 4. Aspectos macro e microscópicos de pulmões de ratos infectados com $S$. venezuelensis (esquerda) e tratados com dexametasona (direita) após 5 dias de infecção. A: Pulmões contendo focos hemorrágicos recentes (setas) e tonalidade alaranjada, em decorrência das hemorragias prévias (macrófagos com hemossiderina). Notar a presença de aglomerados inflamatórios, iniciando a formação dos granulomas (cabeças de seta); B: Granuloma inicial centrado por fragmentos de larvas (seta); C: Pulmões mostrando focos hemorrágicos difusos por todo órgão; D: Hemorragia alveolar associada a exsudato protéico intra-alveolar, contendo cutículas de larvas de permeio (setas). Aumentos originais: 200x. Coloração HE. Barra: 4mm. 


\section{7ํ dia pós-infecção}

No $7^{\circ}$ dia, não havia mais sinais de hemorragia rece nte no parênquima pulmonar dos animais infectados. Os granulomas estavam bem definidos, compactos, compostos por um maior número de macrófagos e eosinófilos envolvidos por uma trama bem definida de fibras reticulares, bem visualizadas na impregnação com a prata. Parasitas não foram mais encontrados no centro dos granulomas, esses visíveis inclusive na superfície pleural.

Os animais tratados com dexametasona não apresentaram formação de granulomas. Os macrófagos continuavam dispersos nos espaços alveolares, eventualmente em aglomerados, mas sempre dispersos sem sinais de organização. Tramas de fibras reticulares não foram visualizadas envolvendo as células inflamatórias. O infiltrado eosinofílico praticamente desapareceu no eixo axial. A quantidade de cutículas fragmentadas de parasitas diminuiu em relação ao grupo anterior (Fig. 5).

Os grupos-controles ( $C$ e $C D$ ) não mostraram alterações relevantes no parênquima pulmonar. 

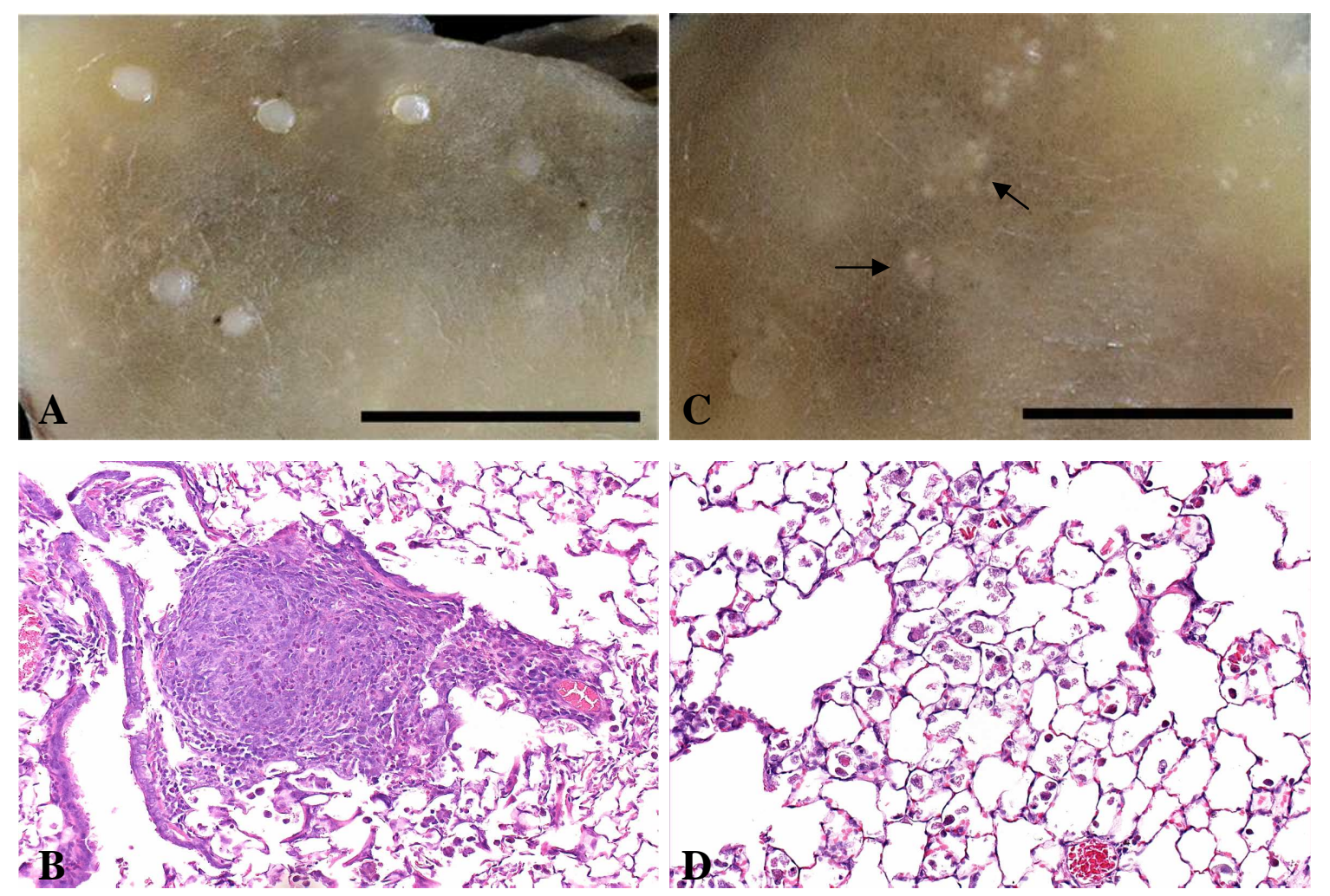

Figura 5. Aspectos macro e microscópicos de pulmões de ratos infectados com $S$. venezuelensis (esquerda) e tratados com dexametasona (direita) após 7 dias de infecção. A: Pulmões exibindo granulomas bem definidos na superfície pleural; B: Granuloma organizado, constituído por células epitelióides, células gigantes e eosinófilos; C: Pulmões com aglomerados inflamatórios na superfície pleural (setas); D: Aglomerados de macrófagos nos espaços alveolares, sem formação de granulomas. Aumentos originais: 200x. Coloração HE. Barra: 4mm. 


\section{4ำ dia pós-infecção}

Após 14 dias de infecção, os granulomas apresentaram-se mais escassos no parênquima alveolar, com aparência menos compacta no grupo infectado. Os eosinófilos praticamente desapareceram no eixo axial, mas continuaram presentes nos granulomas, juntamente com macrófagos, ambos envoltos por fibras reticulares concentricamente arranjadas, embora parasitas não tenham sido visualizados. A arquitetura do pulmão, com exceção dos granulomas, apresentouse preservada.

Os animais tratados do grupo (ID) não apresentaram diferenças quando comparados ao $7^{\circ}$ dia, mas larvas soltas foram encon tradas no parênquima alveolar. Não observamos infiltrado eosinofílico, nem hemorragias alveolares, somente macrófagos contendo hemossiderina dispersos pelos espaços alveolares (Fig. 6).

Os grupos-controles ( $C$ e $C D$ ) não mostraram alterações relevantes no parênquima pulmonar. 

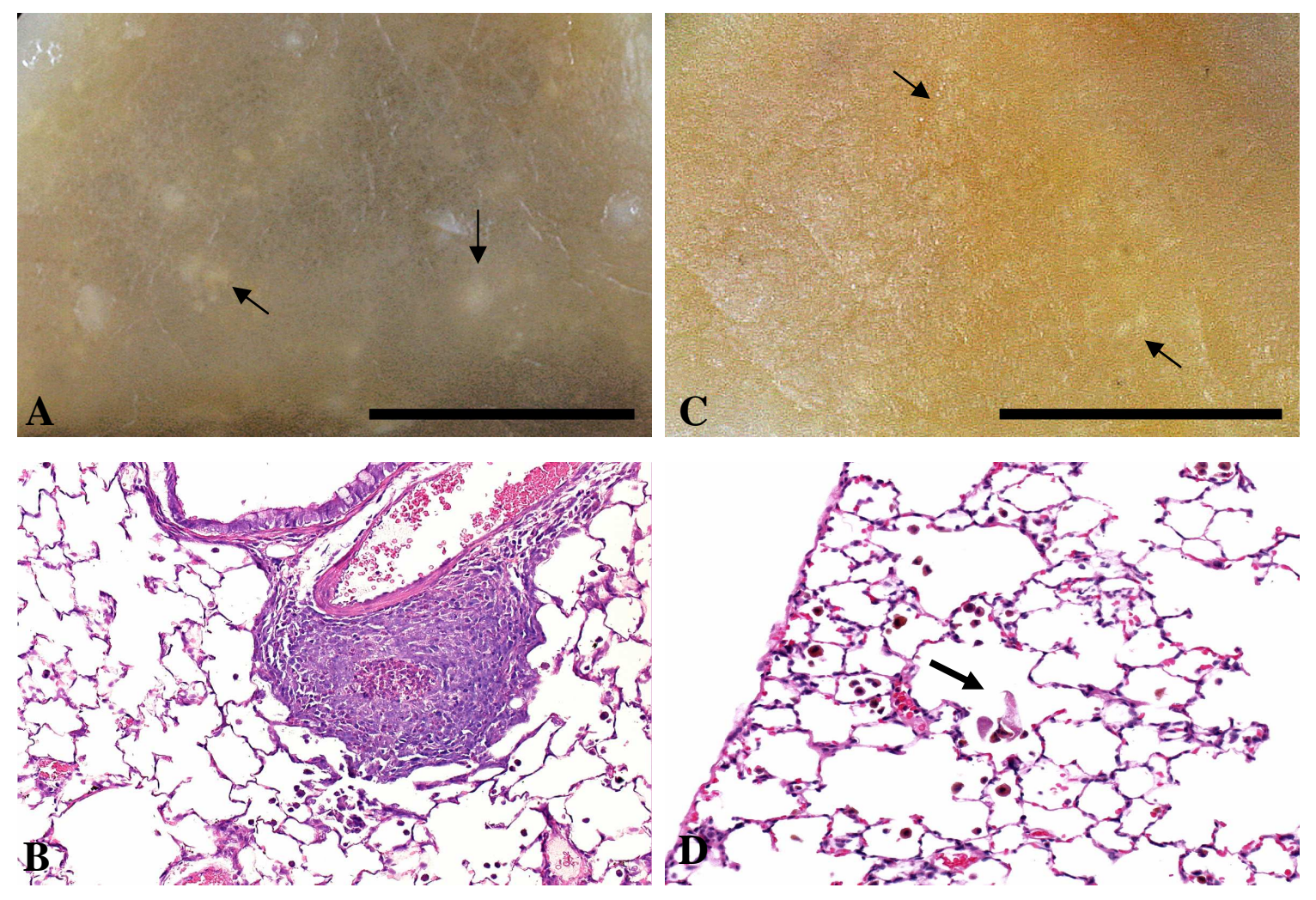

Figura 6. Aspectos macro e microscópicos de pulmões de ratos infectados com $S$. venezuelensis (esquerda) e tratados com dexametasona (direita) após 14 dias de infecção. A: Pulmões com tonalidade levemente alaranjada pelas hemorragias anteriores, mostrando ainda a presença de granulomas (setas); B: Granuloma semelhante ao dia anterior do experimento; C: Pulmões com pigmentação alaranjada (macrófagos com hemossiderina) e focos esparsos de aglomerados de células inflamatórias (setas); D: Macrófagos com hemossiderina dispersos no parênquima alveolar. Notar a presença de larva no espaço alveolar (seta), caracterizando a autoinfestação. Aumentos originais: 200x. Coloração HE. Barra: 4mm. 


\section{1ํ dia pós-infecção}

Finalmente, no $21^{\circ}$ dia somente granulomas residuais e infiltrado inflamatório mínimo foi observado nos pulmões dos animais infectados. Houve uma quase completa resolução do processo inflamatório em decorrência da passagem das larvas do parasita.

O grupo infectado-tratado não mostrou diferenças importantes quando comparado ao $7^{\circ}$ e ao $14^{\circ}$ dia. O infiltrado eosinofí lico praticamente desapareceu no eixo axial e larvas soltas não foram mais observadas nos espaços alveolares. Macrófagos com hemossiderina continuavam dispersos no parênquima alveolar (Fig. 7).

Os grupos-controles ( $C$ e $C D$ ) não mostraram alterações relevantes no parênquima pulmonar. 

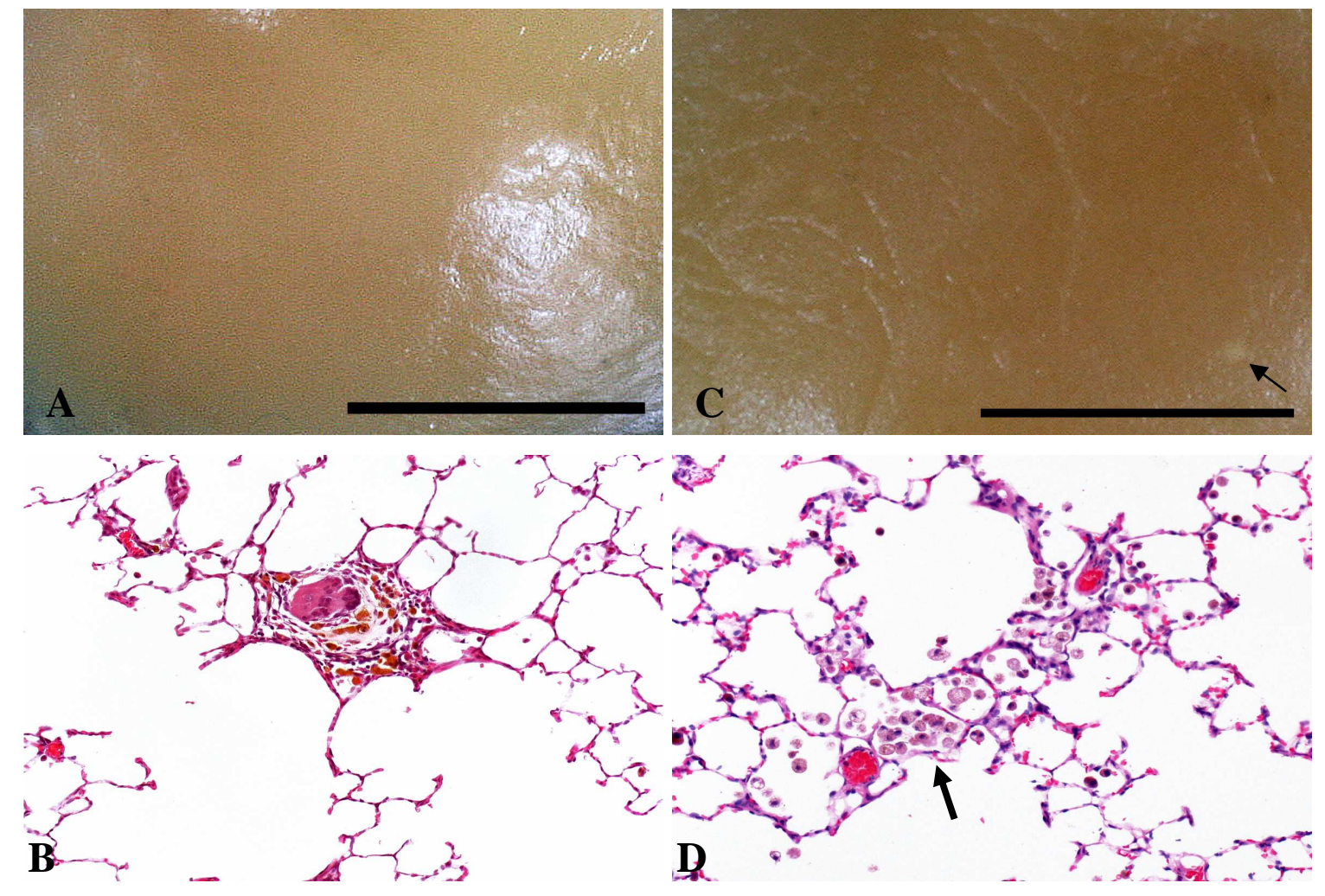

Figura 7. Aspectos macro e microscópicos de pulmões de ratos infectados com $S$. venezuelensis (esquerda) e tratados com dexametasona (direita) após 21 dias de infecção. A: Pulmões praticamente sem alterações, com exceção da discreta tonalidade alaranjada, ainda remanescente na superfície pleural; B: Granuloma residual; C: Pulmões praticamente normais, pigmentação alaranjada devido à presença de macrófagos com hemossiderina; D: Aglomerado de macrófagos xantomatosos e/ou contendo hemossiderina (seta). Aumentos originais: 200x. Coloração HE. Barra: 4mm. 


\subsection{ANÁLISE QUANTITATIVA DE MASTÓCITOS NO EIXO AXIAL (INTERSTÍCIO PERIBRONCOVASCULAR)}

No grupo infectado, houve aumento no número de mastócitos no eixo peribrancovascular desde o primeiro dia pós-infecção. Esse aumento foi significativo no terceiro dia $(2.2 \pm 0.5 ; P<0.001)$, com posterior redução gradual até $07^{\circ}$ dia. Houve um novo pico de mastócitos no $14^{\circ}$ dia após a infecção $(2.8 \pm$ $0.5 ; P<0.001)($ Fig. 8, 9).

Os grupos-controles não mostraram alterações significativas.

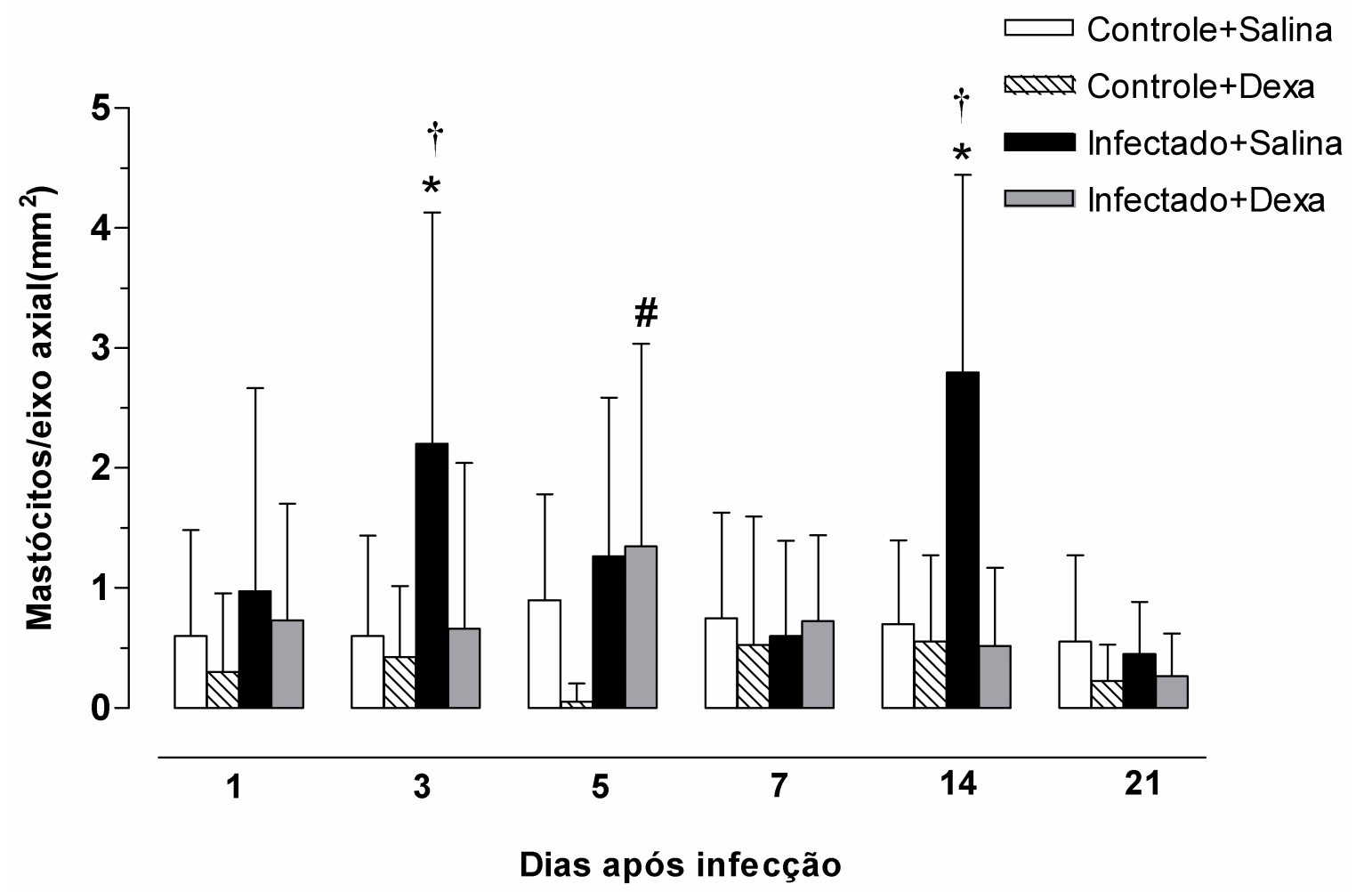

Figura 8. Distribuição dos mastócitos no eixo axial. Houve aumento do número de mastócitos nos dias 3 e 14 nos animais infectados. Os demais grupos não apresentaram aumento destas células. O símbolo * representa diferença significativa entre os animais infectados em relação ao grupo infectado e tratado, $\dagger$ animais infectados em relação ao controle, \# animais infectados e tratados em relação aos animais controle tratados $(P<0.05)$. Os resultados são expressos como média \pm SD $(\mathrm{n}$ : 6/dia/grupo). 
Controles
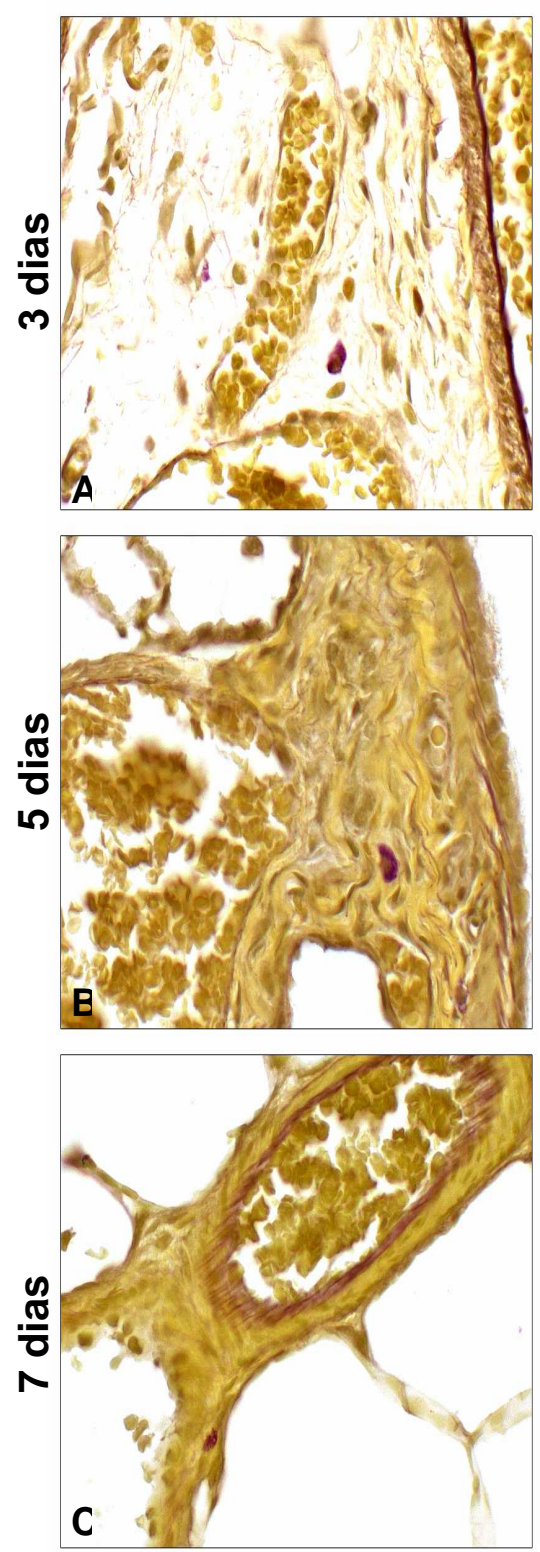

Infectados
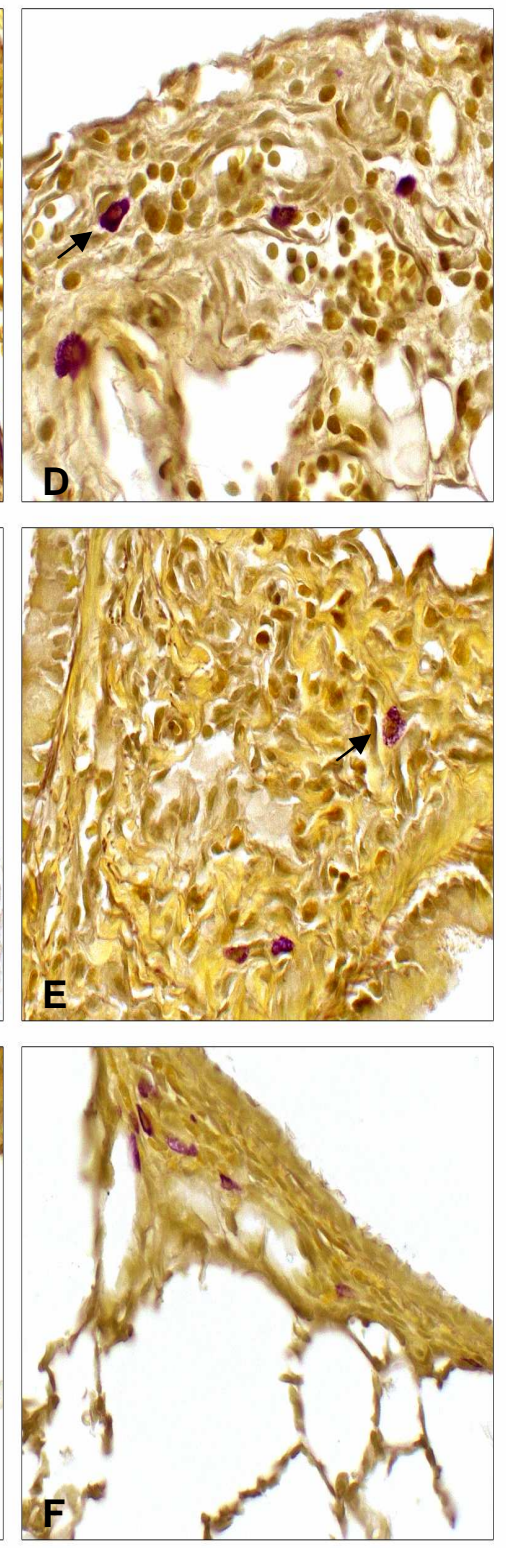

Infectados e Tratados
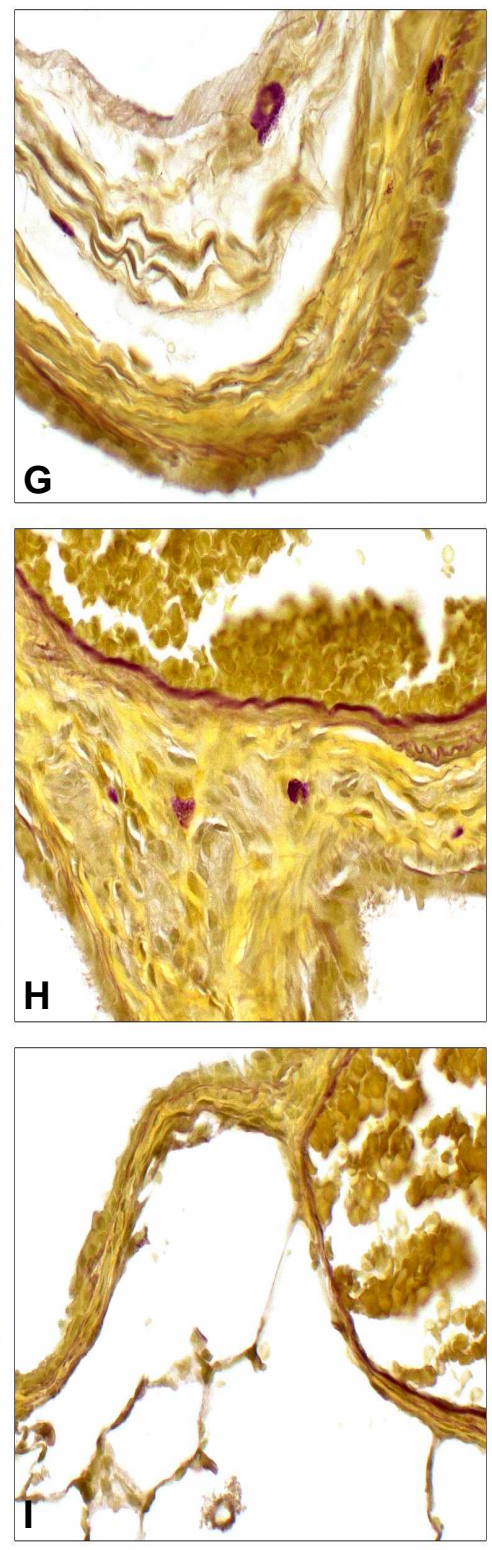

Figura 9. Fotomicrografia dos mastócitos no eixo axial (peri-broncovascular) nos controles (A-C), infectados com $S$. venezuelensis (D-F) e tratados com dexametasona (G-I) com 3, 5 e 7 dias pós-infecção. Notar a maior quantidade de mastócitos no eixo axial dos animais infectados (setas), em relação aos dois outros grupos. Aumentos originais: 200x. Coloração Luna. 


\subsection{ANÁLISE QUANTITATIVA DO INFILTRADO EOSINOFÍLICO NO EIXO AXIAL (INTERSTÍCIO PERIBRONCOVASCULAR)}

A infecção por $S$. venezuelensis induziu um aumento significativo do número de eosinófilos no parênquima pulmonar. No grupo infectado, a migração ocorreu para o eixo axial (tecido peri-broncovascular) já no $1^{\circ}$ dia pós-infecção $(8.8 \pm 5.6, P<$ 0.001), quando comparado com os demais grupos. O número de eosinófilos alcançou um pico no $3^{\circ}$ dia $(67.5 \pm 23.2 ; P<0.001)$ quando comparado com os controles. No $5^{\circ}$ dia, houve uma pequena redução des ses números $(61 \pm 19.5, P<$ 0.001). A partir do $7^{\circ}$ dia, o número de eosinófilos teve uma redução significativa (26.6 $\pm 7.4 ; P<0.001)$. No $14^{\circ} \mathrm{dia}$, o infiltrado eosinofílico red uziu drasticamente (4.6 $\pm 4.6 ; P<0.05)$, quando comparado com os demais grupos. No último dia do experimento, os eosinófilos tiveram um novo pico (20.7 $\pm 7.3 ; P<0.001)$, quando comparado com os demais grupos.

Ao contrário, no primeiro dia de infecção, praticamente não visualizamos eosinófilos no eixo axial $(0.6 \pm 0.8)$ dos animais infectados e tratados com dexametasona. Entretanto, no $3^{\circ}$ dia, esse grupo exi biu um aumento significativo de eosinófilos, embora menos proeminente que o grupo anterior (49 \pm 21.9 ; $P<$ 0.05). Após isso, houve uma redução importante do número de eosinófilos no $5^{\circ}$ dia $(22.8 \pm 10.6 ; P<0.001)$ e a partir do $7^{\circ}$ dia, praticamente os eosi nófilos não foram mais identificados no eixo axial, até o final do experimento $(1.6 \pm 1.4 ; 0.9 \pm$ 1.0; $0.7 \pm 0.9$, nos dias 7, 14 e 21, respectivamente) (Fig. 10, 11).

Os grupos (C) e (CD) não mostraram infiltrado eosinofílico importante no eixo axial. 


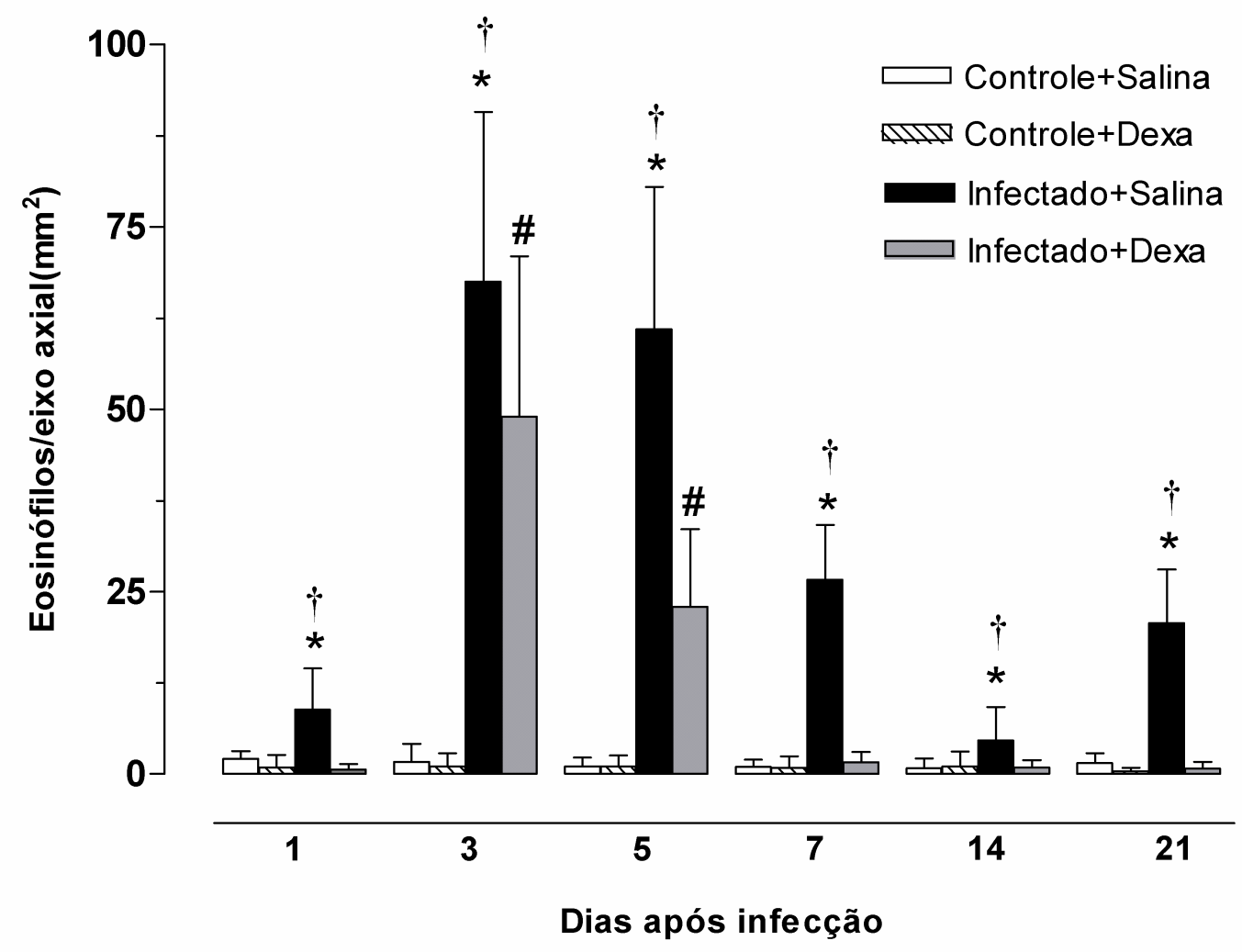

Figura 10. Distribuição dos eosinófilos no eixo axial. O pico do infiltrado eosinofílico ocorreu no $3^{\circ}$ dia nos animais infectados, com redução gradual a partir do $5^{\circ}$ dia. Este padrão se repetiu nos animais infectados e tratados, embora menos proeminentes. $O$ símbolo * representa diferença significativa entre os animais infectados em relação ao grupo infectado e tratado, $\dagger$ animais infectados em relação ao controle, \# animais infectados e tratados em relação aos animais controle tratados $(P<0.05)$. Os resultados são expressos como média \pm SD (n: 6/dia/grupo). 

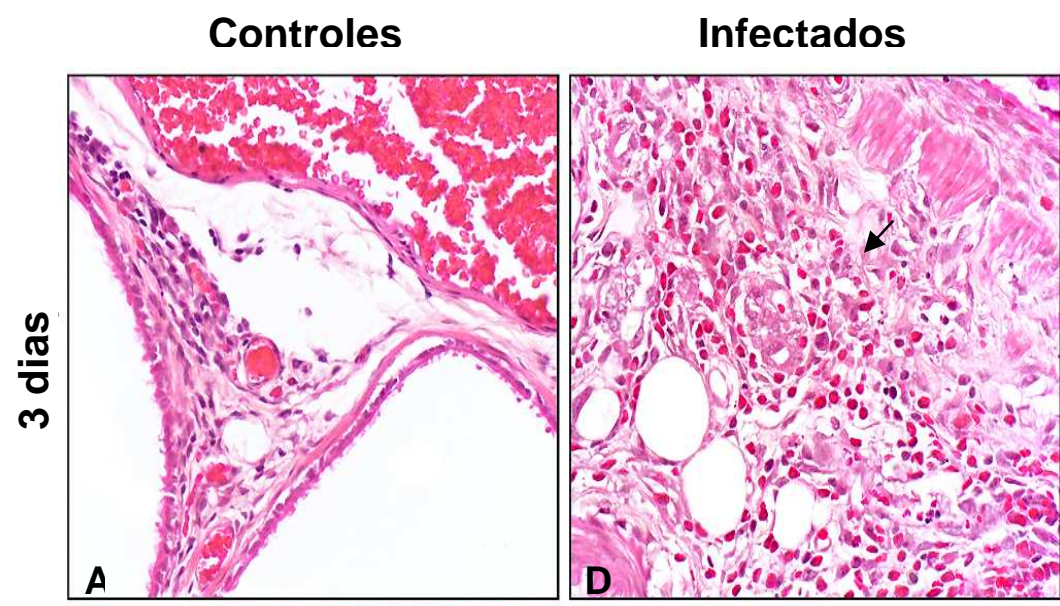

Infectados e Tratados
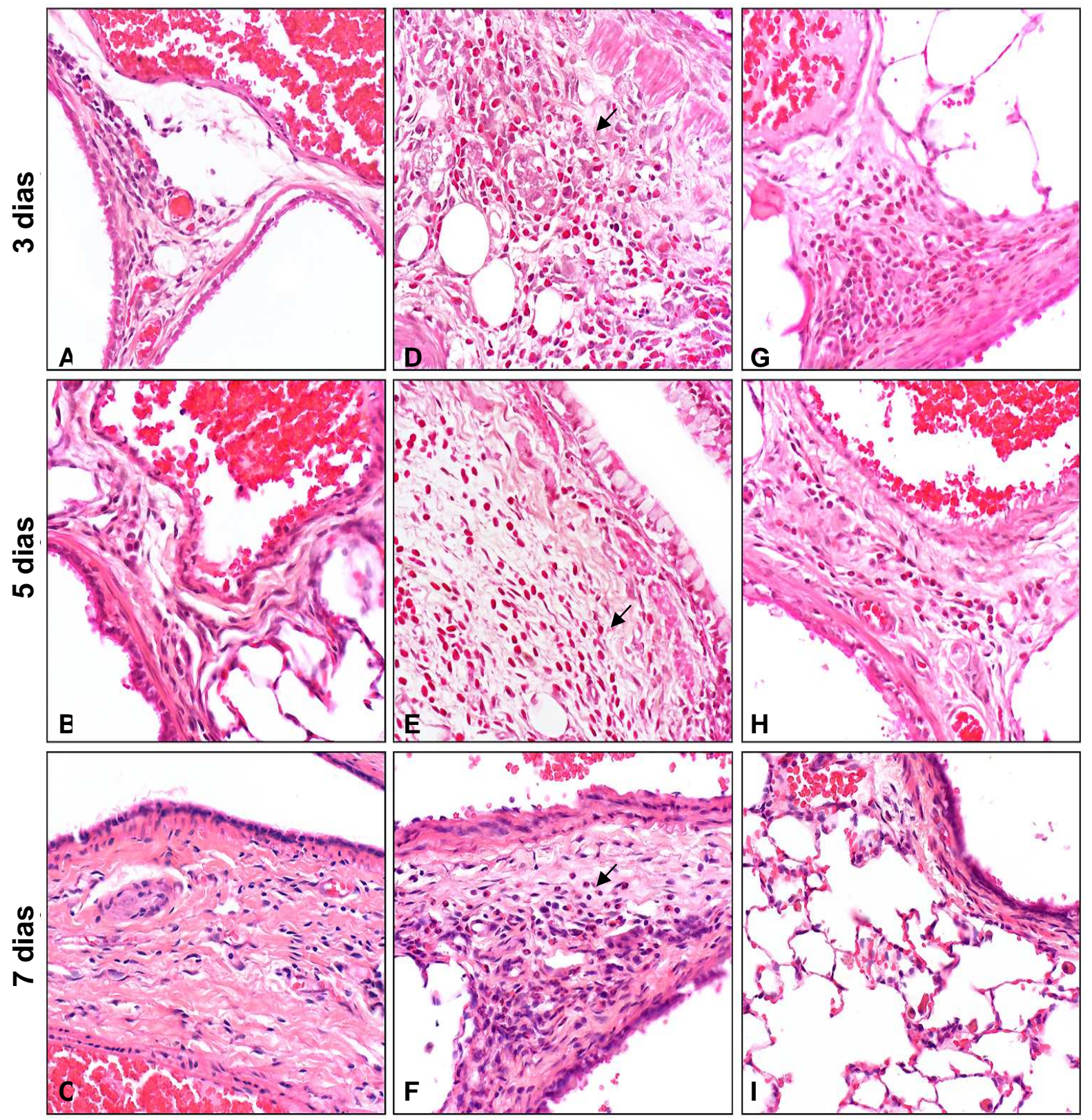

Figura 11. Fotomicrografia do infiltrado eosinofílico no eixo axial (peri-broncovascular) de ratos controle (A-C), infectados com $S$. venezuelensis (D-F) e tratados com dexametasona (G-I) com 3, 5 e 7 dias. Notar a maior quantidade de eosinófilos no 3 e 5o dia pós-infecção, no eixo axial dos animais infectados (setas), em relação aos dois outros grupos. Aumentos originais: 200x. Coloração HE. 


\subsection{ANÁLISE QUANTITATIVA DO INFILTRADO EOSINOFÍLICO NO PARÊNQUIMA ALVEOLAR}

A presença de eosinófilos no parênquima pulmonar alveolar só foi detectada na microscopia óptica convencional a partir do $5^{\circ}$ dia após a infecção, coincidindo com o início da organização do processo inflamatório em granulomas $(4.6 \pm 7.0)$. A partir do $7^{\circ}$ dia, os eosinófilos eram proeminentes na estrutura do granuloma (49 \pm 24.5; $P<0.001)$, atingindo pico máximo no $14^{\circ}$ dia $(64.6 \pm 36 ; P<0.001)$. No $21^{\circ}$ dia, os eosinófilos praticamente desapareceram do parênquima pulmonar (3.6 \pm 3.6) (Fig. 12, 15).

Os demais grupos, inclusive o grupo infectado e tratado com dexametasona, não apresentaram infiltrado eosinofílico relevante no parênquima alveolar em nenhuma etapa do experimento (Fig. 12, 16).

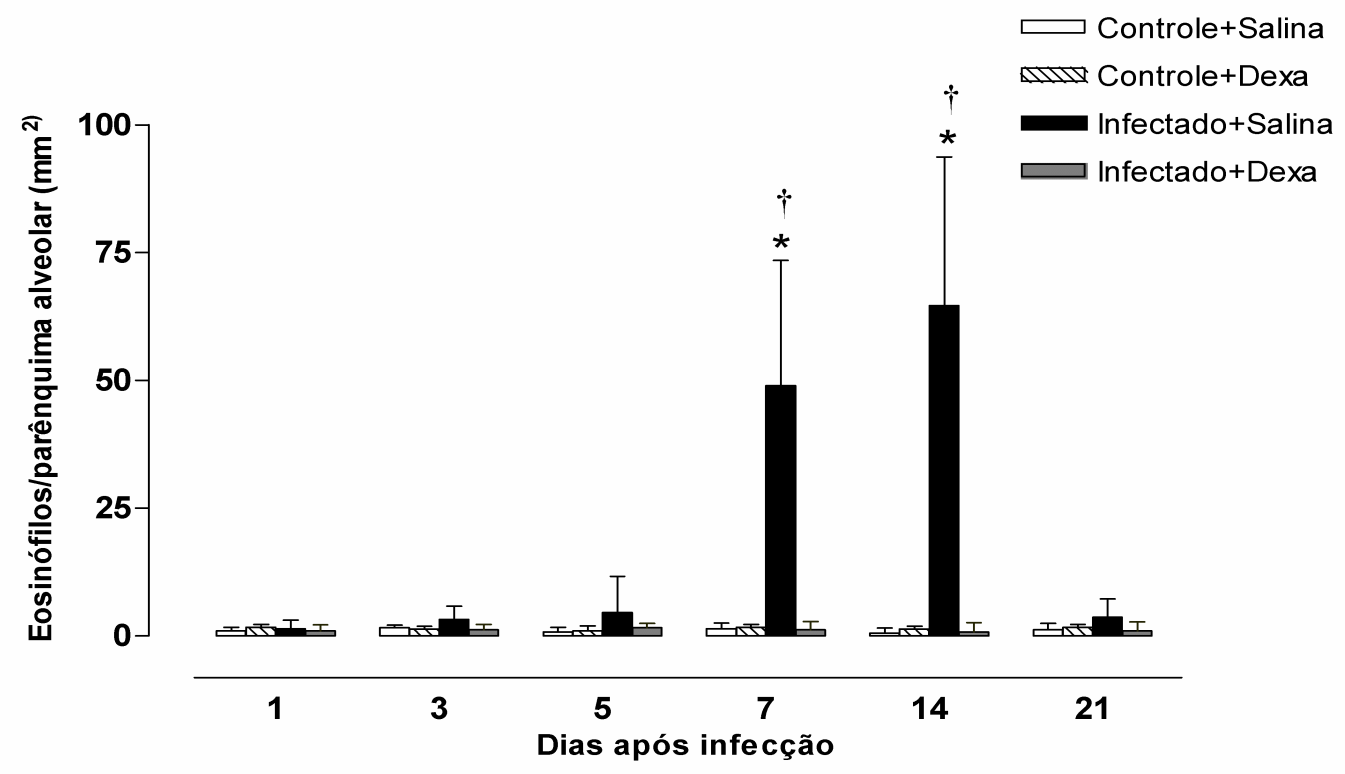

Figura 12. Distribuição dos eosinófilos no parênquima alveolar. Notar o aumento gradual de eosinófilos no parênquima alveolar, a partir do $5^{\circ}$ dia, nos animais infectados, coincidindo com o início da formação dos granulomas. Após o pico, no $14^{\circ}$ dia, os eosinófilos praticamente desaparecem do parênquima alveolar, juntamente com os granulomas. Ao contrário, não detectamos a presença de eosinófilos no parênquima alveolar nos animais infectados e tratados e nos controles. O símbolo * representa diferença significativa entre os animais infectados em relação ao grupo infectado e tratado, $†$ animais infectados em relação ao controle, \# animais infectados e tratados em relação aos animais controle tratados $(P<0.05)$. Os resultados são expressos como média \pm SD (n: 6/dia/grupo). 


\subsection{ANÁLISE QUANTITATIVA DOS MACRÓFAGOS NO PARÊNQUIMA}

ALVEOLAR POR ESTEREOLOGIA

Os animais infectados apresentaram um aumento do número de macrófagos no primeiro dia de infecção $(1 \pm 0.5 ; P<0.001)$ quando comparado com os grupos controles. Este aumento foi progressivo, atingindo um pico no $5^{\circ}$ dia $(1.7 \pm 0.7$ e $3 \pm$ $0.8 ; P<0.001$, respectivamente nos dias 3 e 5), quando comparado aos demais grupos. A partir do $7^{\circ}$ dia, houve redução significa tiva no número de macrófagos até o final do experimento $(1.2 \pm 0.4 ; 0.7 \pm 0.2 ; 0.5 \pm 0.4$, nos dias 7,14 e 21 , respectivamente). A diminuição no número de macrófagos foi simultânea à formação dos granulomas (Fig. 13, 15).

O grupo tratado com dexametasona mostrou um aumento de macrófagos no primeiro dia, no entanto, inferior aos animais infectados $(0.6 \pm 0.3, P<0.01)$. Esse aumento foi progressivo, atingindo um pico no $5^{\circ}$ dia e mantendo-se em níveis aumentados até o fim do experimento $(1.2 \pm 0.5 ; 2.2 \pm 0.8 ; 2.3 \pm 0.6 ; 2 \pm 0.8 ; 2 \pm$ $0.6 ; P<0.001$, nos dias 3,5, 7, 14 e 21, respectivamente). Nesse grupo, não houve formação de granulomas (Fig. 13, 16).

Os grupos controles não mostraram aumento de macrófagos no parênquima alveolar. 


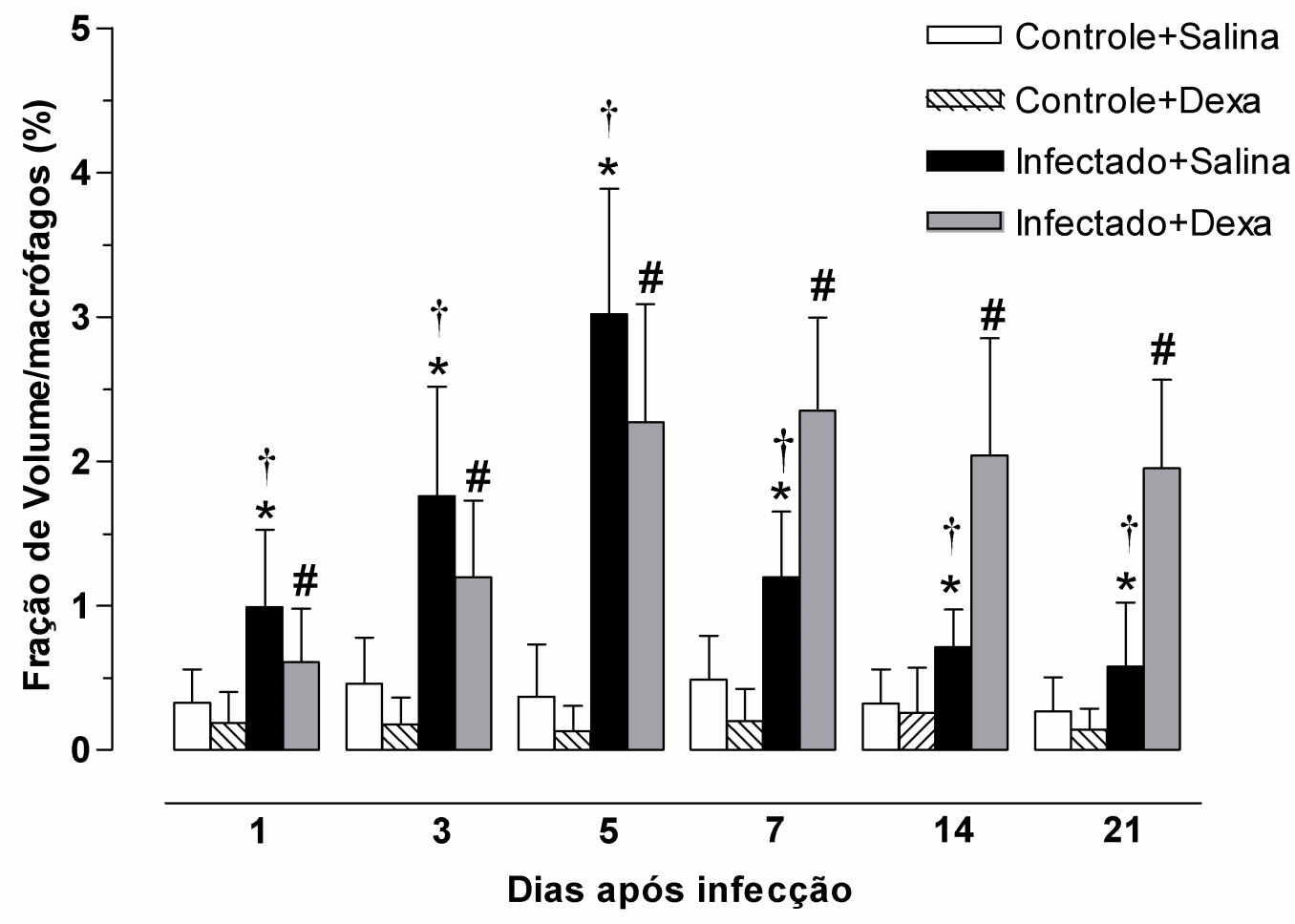

Figura 13. Distribuição dos macrófagos no parênquima alveolar através de estereologia. Notar a redução significativa dos macrófagos presentes nos espaços alveolares, coincidindo com o início da organização dos granulomas, nos animais infectados. A falta de organização destas células é bem demonstrada nos animais infectados e tratados, com distribuição aleatória dos macrófagos até o final do experimento. O símbolo * representa diferença significativa entre os animais infectados em relação ao grupo infectado e tratado, $†$ animais infectados em relação ao controle, \# animais infectados e tratados em relação aos animais controle tratados $(P<0.05)$. Os resultados são expressos como média $\pm \mathrm{SD}(\mathrm{n}$ : 6/dia/grupo). 


\subsection{ANÁLISE DA PRESENÇA DE FIBRAS RETICULARES COMPONDO O PROCESSO INFLAMATÓRIO}

A presença de fibras reticulares permeando o processo inflamatório foi detectada a partir do $5^{\circ}$ dia após a infecção, coinc idindo com a organização do processo inflamatório em granulomas. Essa trama envolvia o parasita e as células inflamatórias, notavelmente eosinófilos e macrófagos, contribuindo para a conformação geométrica usual dos granulomas. O aumento das fibras reticulares foi gradual $(6.2 \pm 1.5,15.3 \pm 1$ e $16.1 \pm 2$ nos dias 5,7 e 14 , respectivamente), com significância estatística quando comparado aos demais grupos. No final do experimento, as fibras reticulares tenderam a desaparecer juntamente com os granulomas $(5.0 \pm 1.6)($ Fig 14, 15) .

O grupo ID também apresentou um pequeno aumento na quantidade de fibras reticulares no parênquima alveolar $(4 \pm 0.3,3 \pm 0.3$ e $6.8 \pm 1$, nos dias 5,7 e 14 , respectivamente), entretanto, essas fibras, visivelmente, ficaram restritas aos septos alveolares. Não foram visualizadas fibras reticulares entremeadas com os macrófagos, visualizados sempre dispersos, no parênquima pulmonar (Fig 14, 16).

Os grupos controles não mostraram alterações significantes no percentual de fibras reticulares. 


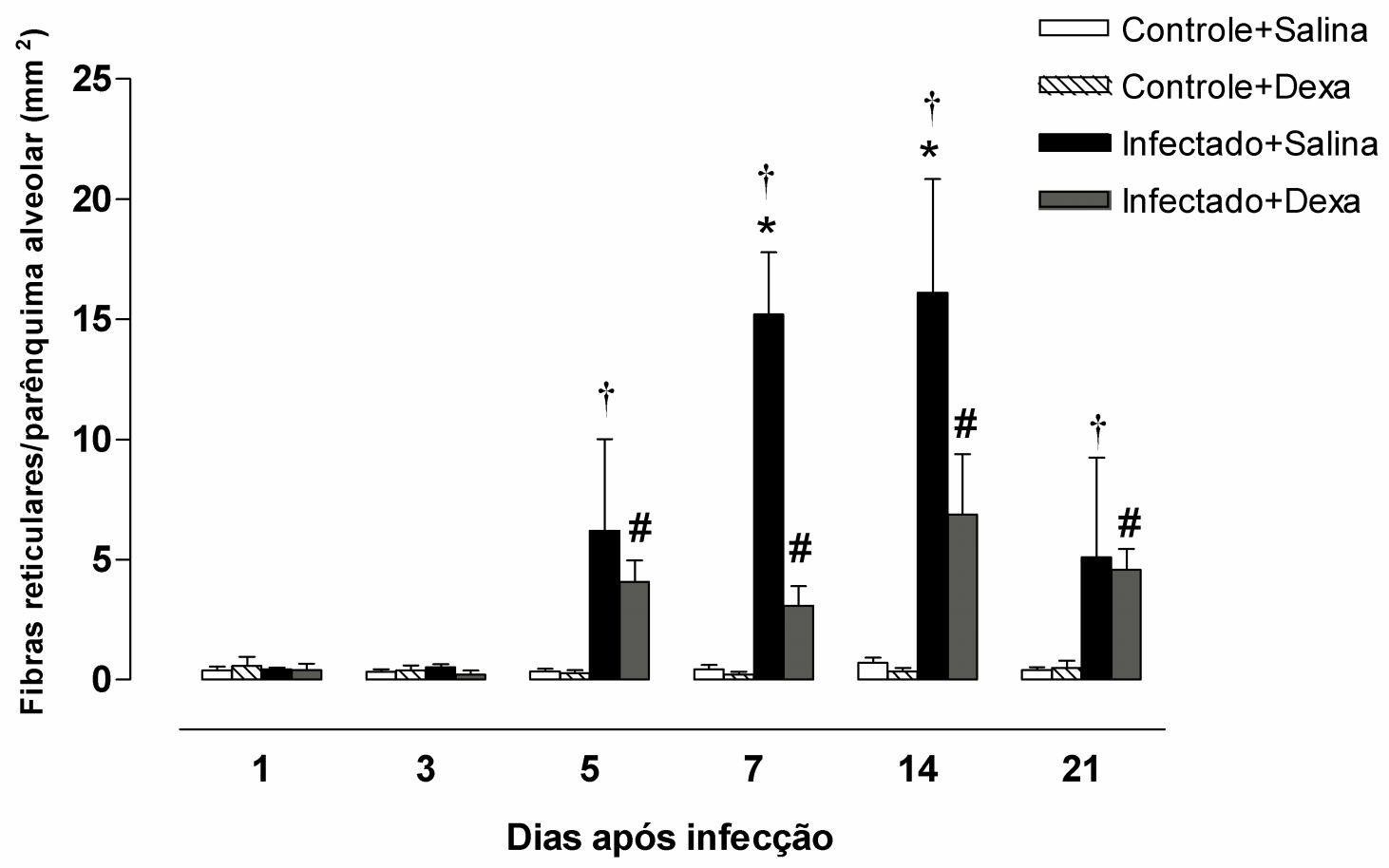

Figura 14. Densitometria (\%) das fibras reticulares no parênquima alveolar nos granulomas ou em áreas com aglomerados de macrófagos. Houve um aumento das fibras reticulares envolvendo os granulomas a partir do $5^{\circ}$ dia nos animais infectados. No $7^{\circ}$ dia, as fibras aumentaram e se mantiveram até o 14ํㅡㄹ dia de infecção. Os animais infectados e tratados apresentaram um pequeno aumento restrito aos septos alveolares a partir do $5^{\circ}$ dia. O símbolo * representa diferença significativa entre os animais infectados em relação ao grupo infectado e tratado, † animais infectados em relação ao controle, \# animais infectados e tratados em relação aos animais controle tratados $(P<$ $0.05)$. Os resultados são expressos como média \pm SD (n: 6/dia/grupo). 


\section{Infectados}

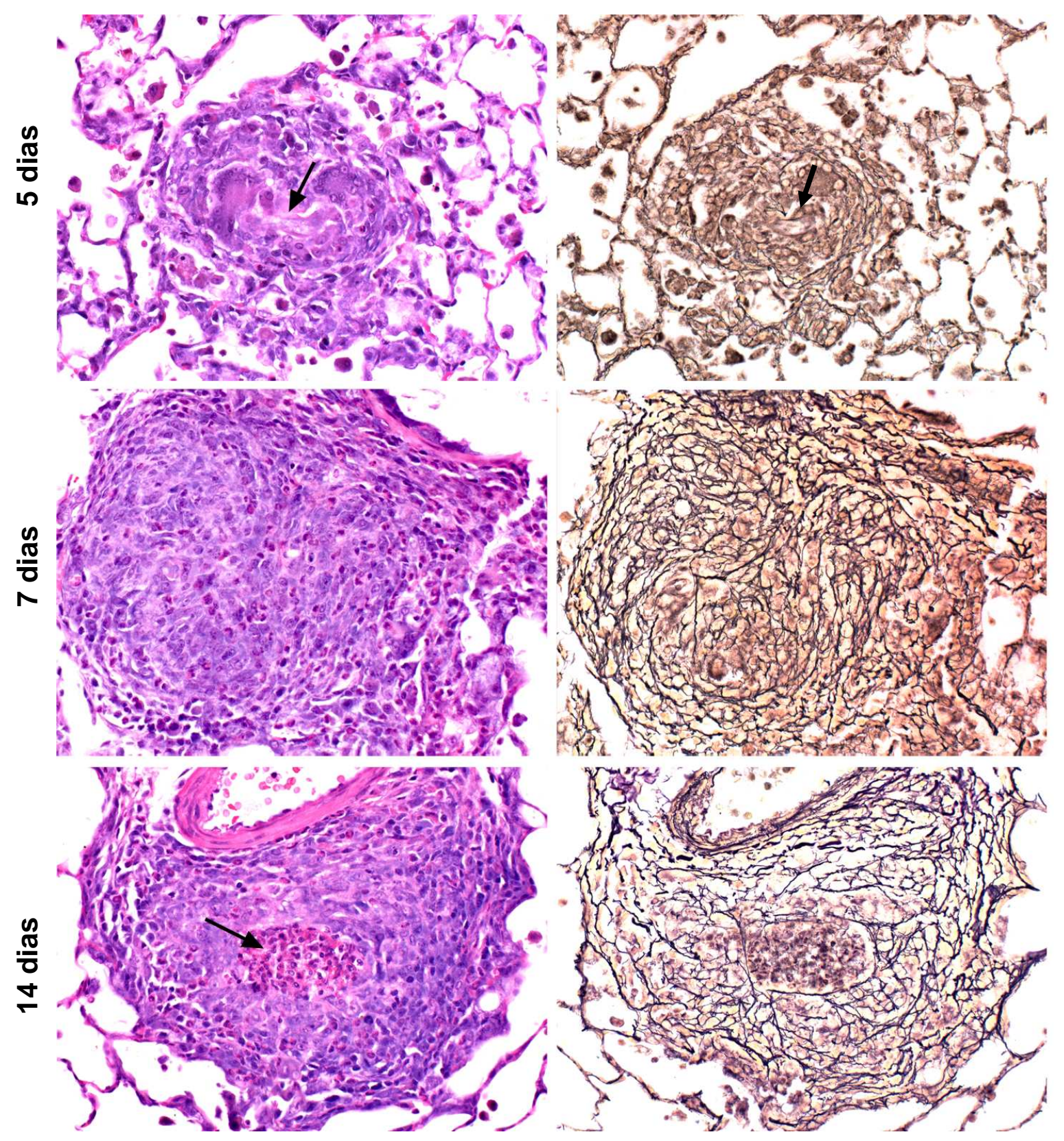

Figura 15. Detalhe dos granulomas visualizados no parênquima alveolar dos animais infectados com Strongyloides venezuelensis. Observar a composição dos granulomas (eosinófilos, macrófagos, células gigantes e fragmentos de larvas (setas no $5^{\circ}$ dia). Os granulomas são envoltos por uma rede de fibras reticulares, com arranjo concêntrico, ancorando as células inflamatórias e aprisionando o parasita. Notar a maior densidade desta trama no $7^{\circ}$ dia do experimento, coincidindo com o aspecto bem definido exibido na macroscopia (vide Fig. 5).

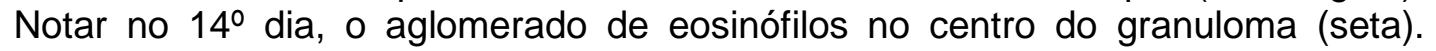
Aumentos originais: 400x. Colorações HE (esquerda) e reticulina de Gomori (direita). 


\section{Infectados e Tratados}
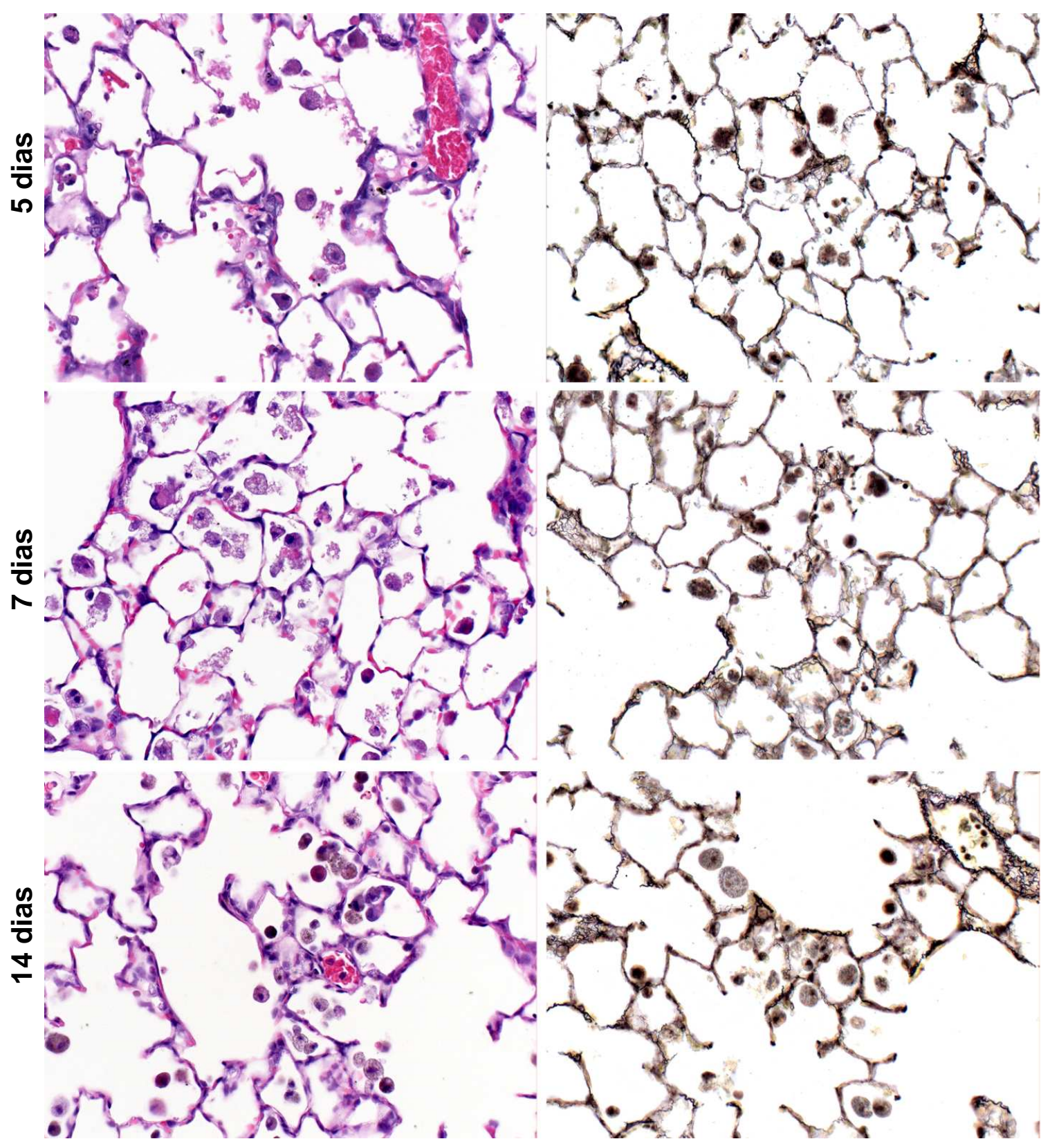

Figura 16. Detalhe dos aglomerados inflamatórios, visualizados no parênquima alveolar dos animais infectados com Strongyloides venezuelensis e tratados com dexametasona. Observar a ausência de granulomas e/ou trama de fibras reticulares. Aumentos originais: 400x. Colorações: HE (esquerda) e reticulina de Gomori (direita) 


\section{DISCUSSÃO}

O tratamento diário com a dexametasona promoveu diversas alterações na resposta inflamatória do hospedeiro, durante a passagem das larvas do Strongyloides venezuelensis pelo parênquima pulmonar. Quatro principais alterações são destacadas a seguir: 1) redução de peso dos animais controles/infectados tratados; 2) exacerbação da inflamação hemorrágica provocada pela passagem das larvas para o espaço alveolar; 2) diminuição significativa na migração de eosinófilos e mastócitos para o eixo axial pulmonar durante os primeiros dias de infecção, 3) ausência de formação da trama de fibras reticulares em torno das larvas, impedindo a organização do granuloma.

\subsection{ESTADO GERAL DOS ANIMAIS}

O tratamento com dexametasona induziu alterações com perda de massa muscular nos animais infectados e também nos animais controles. Os glicocorticóides estão envolvidos no controle do metabolismo energético e no peso corporal. O modelo experimental de infecção induzida por Strongyloides venezuelensis cujos hospedeiros são os roedores, tem sido amplamente utilizado para investigação dos vários aspectos patológicos e imunológicos, pois esse modelo assemelha-se consideravelmente à situação clínica da infecção humana. No presente estudo, os animais controles tratados com dexametasona e os infectados com S. venezulenesis e tratados com a dexametasona apresentaram significativa perda de peso, quando comparados aos animais somente infectados e controles.

De acordo com dados da literatura, o uso contínuo em excesso de glicocorticóides reduz significativamente a massa muscular, principalmente através 
da perda de proteínas miofibrilares, diminuindo a força e a atividade motora da musculatura de animais (SEENE et al., 2003) e humanos (ATTIX et al., 2005). Os glicocorticóides estão envolvidos no controle do metabolismo energético podendo levar à perda de peso.

Corticóides sintéticos como a dexametasona ligam-se com alta afinidade aos receptores que têm um efeito catabólico envolvendo perda de peso, lipólise acelerada e diminuição da ingestão de comida (FRANCO-COLIN et al.,2006). A diminuição da massa muscular ocorre através da inibição da síntese protéica e aumento do catabolismo protéico com balanço nitrogenado negativo (VALENTE; ATALLAH, 2001).

\subsection{INFLAMAÇÃO HEMORRÁGICA ALVEOLAR}

A hemorragia alveolar pode apresentar-se pela a manifestação de uma gama variada de doenças e o processo comum a todas elas é um sangramento difuso nos alveolos pulmonares. Histopatologicamente, pode haver um infiltrado celular, resultando num espessamento do espaço intersticial formado por edema e depósito de fibrina. Este processo geralmente leva a necrose fibrinóide lesando também a membrana basal dos capilares alveolares e permitindo 0 extravasamento de fibrina e hemácias para a luz alveolar, caracterizando a hemorragia (COHEN, 2002).

Nossos resultados mostraram que a resposta inflamatória provocada pela passagem das larvas do S. venezuelensis pelos capilares pulmonares durante sua rota natural de migração para o trato gastrointestinal foi modificada pelo uso diário da dexametasona. O aspecto multifocal da hemorragia alveolar nos animais infectados foi substituído por um aspecto confluente e bilateral, nos animais 
infectados e tratados, com aumento de edema e depósitos de fibrina, comprometendo quase $100 \%$ dos pulmões.

Embora, o mecanismo exato que induz a formação dos focos hemorrágicos não esteja esclarecido, dados da literatura tem demonstrado que durante a migração das larvas pode ocorrer o rompimento dos capilares alveolares, já que o comprimento das larvas $(15-20 \mu \mathrm{m})$ é bem maior que o tamanho médio dos capilares pulmonares $(7-10 \mu \mathrm{m})$, facilitando desta forma, 0 aparecimento de hemorragia (WERTHEIM, 1970). Apesar da lesão mecânica ocasionada pela migração das larvas levar ao aparecimento de hemorragia, outros fatores podem estar envolvidos nesse processo, uma vez que os focos hemorrágicos persistem mesmo após a migração do parasita para o intestino. Isto sugere que a lesão vascular que segue após a infecção pode ser mediada também por mecanismos imunológicos (GENTA; HAQUE, 1997).

Outra possibilidade seria que o tratamento dos animais com dexametasona poderia promover o aumento do número de larvas e cutículas nos espaços alveolares, ocasionando a exacerbação dos focos hemorrágicos. Uma possível explicação para este fato seria a maior demanda de larvas nos animais infectados e tratados. Estudos têm proposto que a administração de corticóides pode aumentar a produção de moléculas ecdysteroid-like, hormônios que controlam as mudas das larvas do Strongyloides stercoralis (GROVE, 1996). Isso levaria a uma aceleração nas mudas do parasita, com transformação das larvas rabditóides em larvas filarióides invasivas, promovendo hiperinfecção e disseminação das larvas nos tecidos (GENTA, 1992).

Após a passagem da maioria das larvas pelo pulmão que ocorreu aproximadamente no $3^{\circ}$ dia de infecção, a hemorragia alveolar estava quase 
completamente resolvida, provavelmente devido à fagocitose das hemácias pelos macrófagos alveolares residentes e/ou recém-chegados em decorrência em processo inflamatório. Conseqüentemente, um grande número de macrófagos contendo hemossiderina puderam ser visualizados nos espaços alveolares. $\mathrm{Na}$ avaliação microscópica, não foram visualizadas alterações residuais significativas na trama capilar pulmonar que restaurou completamente sua integridade. Entretanto, nos animais submetidos ao tratamento com dexametasona, observamos a presença de hemorragia crônica com presença de grandes quantidades de macrófagos contendo hemossiderina, que persistiram até o final do experimento. Apesar da presença de hemorragia crônica, provavelmente provocada pelo rompimento dos capilares pulmonares, não foram evidenciadas alterações estruturais relevantes, bem como, não houve o comprometimento funcional do parênquima pulmonar.

\subsection{MIGRAÇÃO DE EOSINÓFILOS E MASTÓCITOS NO EIXO AXIAL}

Nossos resultados demonstraram que a infecção por S. venezuelensis é capaz de induzir eosinofilia pulmonar, corroborando com dados já existentes na literatura (KORENAGA et al., 1991, SILVEIRA et al., 2002). Em algumas condições inflamatórias, como nas infecções por nematódeos com ciclo pulmonar, os eosinófilos atuam mediando as funções inflamatórias e citotóxicas através da produção, regulação e liberação de seus grânulos e pela síntese e produção de numerosas citocinas, quimiocinas e fatores de crescimento (DRUILHE; LÉTUVÉ, PRETOLANI, 2003, WARDLAW, 1999). O recrutamento dos eosinófilos é mediado por uma combinação de moléculas de adesão como a VCAM-1, quimiocinas como a eotaxina e mediadores lipídicos, tais como, o fator ativador de plaquetas (PAF) e 
leucotrienos $\mathrm{LTC}_{4}, \mathrm{LTD}_{4} \mathrm{E} \mathrm{LTC}_{4}$. Serra e colaboradores (2003) demonstraram durante infecção por Angiostrongylus costaricensis que os eosinófilos liberam seus grânulos contendo proteínas catiônicas que são tóxicas para os nematódeos na tentativa de eliminar o parasita. Os eosinófilos também secretam interleucinas próinflamatórias, tais como, IL-2, IL-4, IL-5, IL-10, IL-12 e IL-13, que amplificam a resposta inflamatória Th2 através da ativação de células $\mathrm{T} \mathrm{CD}^{+}$que estão associadas com a resistência à infecção não apenas pelo $S$. stercoralis, mas também pelo S. mansoni e A. Lumbricoides (MAIZELS; YAZDANBAKHSH, 2003; FERREIRA et al., 2007; MACHADO et al., 2007)

Nossos resultados demonstraram neste modelo experimental, que o tratamento com a dexametasona inibiu de forma significativa o número de mastócitos e eosinófilos no parênquima pulmonar, em todos os períodos estudados. A redução significativa do número de eosinófilos está diretamente relacionada à ação dos glicocorticóides que exercem efeito inibitório sobre a síntese e liberação de citocinas incluindo a IL-5 e de quimiocinas tais como a eotaxina, que são essenciais para o recrutamento dessas células, como já descrito em outros modelos experimentais (BARNES, 1998; DRUILHE; LÉTUVÉ; PRETOLANI, 2003).

Os Mastócitos por sua vez, são ativados pela ligação de seus receptores Fc aos antígenos associados a IgE. Após ativação ocorre a secreção de seus grânulos, síntese de mediadores lipídicos e a secreção de citocinas pró-inflamatórias como a IL-4, IL-5, IL-6 E TNF- $\alpha$ (BRADDING, 2003). Nossos resultados mostraram que nos animais infectados e tratados ocorre uma redução significante do número de mastócitos e eosinófilos no interstício peri-broncovascular (eixo axial) durante o período experimental, sugerindo que a dexametasona estaria modulando negativamente a migração destas células para o pulmão. 
O processo inflamatório encontrado em nossos experimentos é similar aos encontrados na asma atópica. Esse padrão de resposta inflamatória possui uma via de resposta comum, caracterizada pela presença de infiltrado eosinofílico e mastocitário, além da hiperplasia das células epiteliais e produção de muco, (VOERINGER et al., 2006, VOERINGER; SHINKAI; LOCKSLEY, 2004). Estudos demonstraram uma redução do número de mastócitos nas biópsias de indivíduos com asma atópica após tratamento com glicocorticóides (JEFFERY, 1992), demonstrando que, possivelmente, essa redução possa ter ocorrido pelo efeito indireto no recrutamento de mastócitos, inibindo a produção das citocinas IL-3 e de "stem cell factor" (SCF), fundamentais para a migração dessas células (BARNES, 1998).

\subsection{A FORMAÇÃO DO GRANULOMA}

Em nosso estudo foi evidenciado a presença de granulomas nos pulmões de animais infectados com S. venezuelensis. Nossos resultados mostraram uma resposta inflamatória distinta entre os grupos infectados e infectados e tratados. $\mathrm{O}$ pulmão dos animais infectados aprsentaram granulomas bem organizados, compostos basicamente por eosinófilos, macrófagos e células gigantes multinucleadas, envoltos em uma rede de fibras reticulares, centrados ocasionalmente, por fragmentos de larvas. O uso da estereologia ajudou a demonstrar a distribuição espacial do processo inflamatório neste modelo, acusando que a maior quantidade de macrófagos observados no parênquima pulmonar dos animais infectados e tratados, refletiu provavelmente, a ausência de organização celular na formação dos granulomas, demonstrando que os macrófagos sozinhos não conseguem promover o desenvolvimento da rede de 
fibras reticulares. As fibras reticulares presentes nos granulomas são formadas por unidades de fibrilas compostas principalmente por colágeno do tipo III. Estas fibrilas tendem a formar uma delicada rede em torno das células (FAWCETT, 1986), promovendo um ancoradouro para as células inflamatórias na tentativa de conter o parasita e facilitar sua eliminação (LENZI et al.,1999).

Várias hipóteses têm sido aventadas para tentar elucidar a formação do granuloma durante a infecção pelos parasitas. Estudos realizados com diferentes parasitas mostraram que as lesões granulomatosas encontradas no pulmão são resultado de mecanismos imunológicos relacionados com o aumento da produção das citocinas de padrão Th2, tais como, IL-4, IL-5, IL-6 e IL-13 durante o período de desenvolvimento das lesões (MATSUDA et al., 2001, BENBERNOU et al., 1992, CHIARAMONTE et al., 1999). Wynn e colaboradores (1993) demonstraram que durante a infecção por $S$. mansoni há um aumento da expressão de diferentes citocinas, dentre elas o TNF- $\alpha$ que ocorre durante o estágio de crescimento e amadurecimento dos granulomas no pulmão. O TNF- $\alpha$ tem um papel importante na formação e manutenção dos granulomas pela influência na expressão de quimiocinas que atuam diretamente no desenvolvimento da resposta granulomatosa

(ALGOOD; CHAN; FLYNN, 2003).

Segundo a literatura, o principal papel da reação granulomatosa é proteger os tecidos do hospedeiro, sendo um processo dinâmico em que o tamanho e a composição celular das lesões variam com o tempo e é coordenado pela influência de uma rede de mediadores inflamatórios (WYNN; CHEEVER, 1995). A Eosinofilia, quer localizada ou periférica, junto com altas concentrações de IgE no soro, ocorre com freqüência nas infecções por helmintos. Algumas das funções designadas 
para os eosinófilos incluem citotoxidade dependente de anticorpo contra o parasita (ROTHENBERG et al., 1996). Neste estudo, os eosinófilos constituem um dos principais componentes na formação do granuloma. Nossos resultados mostraram no estágio final da infecção, a migração dos eosinófilos para o centro dos granulomas. Os eosinófilos também se organizaram juntamente com os feixes de fibras reticulares formando um padrão circular em torno, provavelmente, dos fragmentos dos parasitas. A partir destes dados, pode-se concluir que os eosinófilos possuem papel importante na formação da reação granulomatosa do hospedeiro e resolução do processo inflamatório causado pelo parasita.

Além da participação direta na formação do granuloma, os eosinófilos também são fonte de várias moléculas (ROBINSON; KAY; WARDLAW, 2002), entre elas: TGF- $\beta$, (KAY; PHIPPS; ROBINSON, 2004;), fator de crescimento fibroblástico-2 (FGF-2) (HOSHINO; TAKAHASHI; AOIKE, 2001), fator de crescimento endotelial vascular (VEGF) (HORIUCHI; WELLER, 1997), metaloproteinase-9 (MMP-9) (OKADA et al., 1997), inibidores de metaloproteinases teciduais específicos 1 (TIMP-1) (LEVI-SCHAFFER et al., 1999), IL-13 (SCHMID-GRENDELMEIER et al., 2002) e IL-17 (MOLET et al., 2001). O TGF- $\beta$ um potente regulador de fibroblastos e miofibroblastos que controlam a produção de várias proteínas da matriz extracelular, incluindo colágenos (MARTIN et al., 1996; OHNO et al., 1996).

Nossos resultados demonstraram o desenvolvimento de uma resposta inflamatória granulomatosa bem definida, aparentemente eficiente na eliminação do parasita, não comprometendo a estrutura alveolar pulmonar, que recuperou sua integridade após a resolução do processo inflamatório, em torno do $21^{\circ}$ dia de infecção. 
Durante todo o período experimental observamos a ausência de resposta granulomatosa nos pulmões dos animais infectados e tratados diariamente com a dexametasona. A ausência dessa resposta pode ter ocorrido, provavelmente, pela inibição da transcrição de várias interleucinas, incluindo IL-4, IL-5, IL-13 e TNF- $\alpha$ (JOYCE; STEER; ABRAHAM, 1997, ALGOOD; CHAN; FLYNN, 2003). Estas citocinas além de promoverem o recrutamento e a ativação de células inflamatórias como eosinófilos e mastócitos poderiam estar envolvidas na formação do granuloma.

Como os eosinófilos não foram visualizados entre os aglomerados de macrófagos no parênquima alveolar no grupo infectado e tratado, isso sugere que essas células possuem um importante papel no desenvolvimento da trama de fibras reticulares através da produção de TGF- $\beta$, que podem ser importantes no depósito de matriz nos pulmões (FLOOD-PAGE et al., 2003, WONG et al., 1990).

A quantificação de citocinas envolvidas no processo inflamatório elicitado pelo parasita se faz necessária para avaliar o efeito da dexametasona, mas podemos sugerir de acordo com nossos dados, que o tratamento com a dexametasona interfere tanto na indução quanto na liberação de citocinas, modulando a resposta imunológica na infecção por S. venezuelensis. 


\section{REFERÊNCIAS}

Abbas AK, Lichtman AH. Imunologia Celular e Molecular. São Paulo. 5a ed. Editora Elsevier, 2005.

Abrahan D, Rotman HL, Haberstroh FH, Yutanawiboonchai W, Brigandi RA, Leon O, Nolan TH, Schad GA. Strongyloides stercoralis protective immunity to third-stage larvae in BALB/cByJ mice. Exp Parasitol 1995;80(2):297-307.

Algood HM, Chan J, Flynn JL. Chemokines and tuberculosis.Cytokine Growth Factor Rev. 2003 Dec;14(6):467-77.

Atkins AS, Lindo JF, Lee MG, Conway DJ, Bailey JW, Robinson RD, Bundy DAP. Humoral responses in human strongiloidiasis: correlations with infection chronicity. Trans Roy Soc Trop Med Hyg 1997;91(5):609-13.

Barnes PJ. Anti-inflammatory actions of glucocorticoids: molecular mechanisms. Clin Sci (Lond) 1998;94:557-72.

Benbernou N, Matsiota-Bernard P, Jolivet C, Ougen P, Guenounou M. Tumour necrosis factor, $\mathrm{IL}-1$ and $\mathrm{IL}-6$ in bronchoalveolar washings and their in vitro production during Nippostrongylus brasiliensis infection. Clin Exp Immunol. 1992 May;88(2):264-8.

Bradding $P$. The role of the mast cell in asthma: a reassessment.Curr Opin Allergy Clin Immunol. 2003 Feb;3(1):45-50.

Carvalho EM, Porto A. Epidemiological and clinical interaction between HTLV-1 and Strongyloides stercoralis. Parasite Immunol 2004;26:487-97.

Chitkara RK, Krishna G. Parasitic pulmonary eosinophilia. Semin Respir Crit Care Med 2006; 27:171-84.

Coffman RL, Seymour BW, Hudak S, Jackson J, Rennick D. Antibody to interleukin5 inhibits helminth-induced eosinophilia in mice. Science. 1989 Jul $21 ; 245(4915): 308-10$.

Cohan VL, Undem BJ, Fox CC, Adkinson NF, Lichtenstein LM, Schleimer RP. Dexamethasone does not inhibit the release of mediators from human lung mast cells residing in airway, intestine or skin. Am Rev Respir Dis 1989;140:951-4.

Cohen S. Diffuse pulmonary hemorrhage: evolutionary 'flaw' or consequence of evolutionary progress? Am J Med Sci. 2002 Mar;323(3):130-9. 
Concha R, Harrington W Jr, Rogers Al. Intestinal strongyloidiasis: recognition, management, and determinants of outcome. J Clin Gastroenterol 2005;39(3):20311.

Druilhe A, Létuvé S, Pretolani M. Glucocorticoid-induced apoptosis in human eosinophils: mechanisms of action. Apoptosis 2003;8:481-95.

Dutcher JP, Marcus SL, Tanowitz HB, Wittner M, Fuks JZ, Wiernik PH. Disseminated strongyloidiasis with central nervous system involvement diagnosed antemortem in a patient with acquired immunodeficiency syndrome and Burkitts lymphoma. Cancer 1990;66(11):2417-20.

Fardet L, Généreau T, Poirot JL, Guidet B, Kettaneh A, Cabane J. Severe strongyloidiasis in corticosteroid-treated patients: case series and literature review. Infect 2007;54(1):18-27.

Fawcett DW. Conective Tissue Proper. In: Histology. W.B Saunders Company/lgaku-ShoinSaunders, $11^{\mathrm{a}}$ ed., 1986, p.136-73.

Ferreira CM, Pereira AT, de Souza RS, Cassali GD, Souza DG, Lemos VS, Teixeira MM, Negrão-Corrêa D. Prevention of changes in airway function facilitates Strongyloides venezuelensis infection in rats. Microbes Infect. 2007 Jun;9(7):81320.

Flood-Page P, Menzies-Gow A, Phipps S, Ying S, Wangoo A, Ludwig MS, Barnes $\mathrm{N}$, Robinson D, Kay AB. Anti-IL-5 treatment reduces deposition of ECM proteins in the bronchial subepithelial basement membrane of mild atopic asthmatics. J Clin Invest. 2003 Oct;112(7):1029-36.

Franco-Colín M, Villanueva I, Piñón M, Racotta R. The effects of sympathectomy and dexamethasone in rats ingesting sucrose. Int J Biol Sci. 2006;2(1):17-22.

Genta RM, Haque Abida. In: Connor DH, Chandler FW, Schawartz DA, Manz HJ, Lack EE. Pathology of Infections Diseases. Stamford, Connecticut:: Appleton\&Lange, 1997, p1567-76.

Genta RM. Dysregulation of strongyloidiasis: a new hypothesis. Clin Microbiol Rev 1992;5:345-55.

Giembycz MA, Lindsay MA. Pharmacology of the eosinophil. Pharmacol Rev 1999;51:213-340.

Grove DI. Human strongyloidiasis. Adv Parasitol 1996;38:251-309.

Grove DI. Strongyloidiasis: a conundrum for gastroenterologists. Gut 1994;35:43740. 
Horiuchi T, Weller PF. Expression of vascular endothelial growth factor by human eosinophils: upregulation by granulocyte-macrophage colony-stimulating factor and interleukin-5. Am J Respir Cell Mol Biol 1997;17:70-7.

Hoshino M, Takahashi M, Aoike N. Expression of vascular endothelial growth factor, basic fibroblast growth factor, and angiogenin immunoreactivity in asthmatic airways and its relationship to angiogenesis. J Allergy Clin Immunol 2001;107:295301.

Jeffery PK, Godfrey RW, Adelroth E, Nelson F, Rogers A, Johansson SA. Effects of treatment on airway inflammation and thickening of basement membrane reticular collagen in asthma: a quantitative light and electron microscopic study. Am Rev Respir Dis 1992;145:890-99.

Joyce DA, Steer JH, Abraham LJ. Glucocorticoid modulation of human monocyte/macrophage function: control of TNF-alpha secretion. Inflamm Res. 1997 Nov;46(11):447-51.

Kay AB, Phipps S, Robinson DS. A role for eosinophils in airway remodelling in asthma. Trends Immunol. 2004 Sep;25(9):477-82.

Keiser PB, Nutman TB. Strongyloides stercoralis in the immunocompromised population. Clin Microbiol Rev 2004;17:208-17.

Klion AD, Nutman TB. The role of eosinophils in host defense against helminth parasites. J Allergy Clin Immunol 2004;113:30-7.

Korenaga M, Hitoshi Y, Takatsu K, Tada I. Regulatory effect of anti-interleukin-5 monoclonal antibody on intestinal worm burden in a primary infection with strongyloides venezuelensis in mice. Int J Parasitol. 1994 Nov;24(7):951-7.

Korenaga M, Hitoshi Y, Yamaguchi N, Sato Y, Takatsu K, Tada I. The role of interleukin-5 in protective immunity to Strongyloides venezuelensis infection in mice. Immunology 1991;72(4):502-7.

Lenzi HL, Kimmel E, Schechtman H, Pelajo-Machado M, Vale BS, Panasco MS, Lenzi JA. Collagen arrangement in hepatic granuloma in mice infected with Schistosoma mansoni: dependence on fiber radiation centers. Braz J Med Biol Res 1999;32:639-43.

Levi-Schaffer F, Garbuzenko E, Rubin A, Reich R, Pickholz D, Gillery P, Emonard $\mathrm{H}$, Nagler A, Maquart FA. Human eosinophils regulate human lung- and skinderived fibroblast properties in vitro: a role for transforming growth factor $\beta$ (TGF- $\beta$ ). Proc Natl Acad Sci U S A 1999;96:9660-5. 
Liberman AC, Druker J, Perone MJ, Arzt E. Glucocorticoids in the regulation of transcription factors that control cytokine synthesis. Cytokine \& growth factor rev 2007;18(1-2):45-56.

Luna L. Manual of histologic staining methods of the armed forces institute of pathology. New York. McGraw-Hill, 1968, p: 114-15.

Machado ER, Ueta MT, Lourenço EV, Anibal FF, Roque-Barreira MC, Faccioli LH. Comparison of immune responses in mice infected with different strains of Strongyloides venezuelensis. Parasite Immunol. 2007 Nov;29(11):549-57.

Maizels RM, Yazdanbakhsh M. Immune regulation by helminth parasites: cellular and molecular mechanisms. Nat Rev Immunol. 2003 Sep;3(9):733-44.

Mandarim-de-Lacerda CA. Stereological tools in biomedical research. An Acad Bras Cienc 2003;75(4):469-86.

Martin LB, Kita H, Leiferman KM, Gleich GJ. Eosinophils in allergy: role in disease, degranulation, and cytokines. Int Arch Allergy Immunol 1996;109:207-15.

Matsuda K, Kim BS, Whang IS, Lim CW, Baek BK. Migration of Strongyloides venezuelensis in rats after oral inoculation of free-living infective larvae. Vet Med Sci 2003;65(9):971-5.

Matsuda S, Tani Y, Yamada M, Yoshimura K, Arizono N. Type 2-biased expression of cytokine genes in lung granulomatous lesions induced by Nippostrongylus brasiliensis infection. Parasite Immunol. 2001 May;23(5):219-26.

McLaren DJ, Ramalho-Pinto FJ, Smithers SR. Ultrastructural evidence for complement and antibody-dependent damage to schistosomula of Schistosoma mansoni by rat eosinophils in vitro. Parasitology. 1978 Dec;77(3):313-24.

Melo AL. Strongyloides stercoralis. In: Neves DP, Melo AL, Genaro O, Linardi PM. Parasitologia humana. São Paulo. $7^{a}$ ed. Editora Atheneu, 1988, p. 297-305.

Molet S, Hamid Q, Davoine F, Nutku E, Taha R, Pagé N, Olivenstein R, Elias J, Chakir J. IL-17 is increased in asthmatic airways and induces human bronchial fibroblasts to produce cytokines. J Allergy Clin Immunol 2001;108:430-38.

Negrão-Corrêa D, Silveira MR, Borges CM, Souza DG, Teixeira MM. Changes in pulmonary function and parasite burden in rats infected with Strongyloides venezuelensis concomitant with induction of allergic airway inflammation. Infect Immun 2003;71:2607-14.

Newton R. Molecular mechanisms of glucocorticoid action: what is important? Thorax. $2000 \mathrm{Jul} ; 55(7): 603-13$. 
Noguchi H, Kephart GM, Colby TV, Gleich GJ. Tissue eosinophilia and eosinophil degranulation in syndromes associated with fibrosis. Am J Pathol 1992;140:521-28.

Ohno I, Nitta Y, Yamauchi K, Hoshi H, Honma M, Woolley K, O'Byrne P, Tamura G, Jordana M, Shirato K. Transforming growth factor beta 1 (TGF beta 1) gene expression by eosinophils in asthmatic airway inflammation. Am $\mathrm{J}$ Respir Cell Mol Biol 1996;15:404-09.

Okada S, Kita H, George TJ, Gleich GJ, Leiferman KM. Migration of eosinophils through basement membrane components in vitro: role of matrix metalloproteinase9. Am J Respir Cell Mol Biol 1997;17:519-28.

Onah DN, Nawa Y. Mucosal immunity against parasitic gastrointestinal nematodes. Korean J Parasitol 2000;38(5):209-36.

Parfitt K. Corticosteroids. Martindale: The complete drug reference, $32^{\mathrm{a}}$ ed. London: Pharmaceutical Press, 1999, p.1010-51.

Pellizzon CH, Faccioli LH, Mokwa VF, Gomes JC, Lunardi LO. Participação de mastócito e basófilo na resposta inflamatória pulmonar em cobaias infestadas por Toxocara canis. In IX Reunião Anual da Federação de Sociedades de Biologia Experimental, Anais, 1996. p.202.

Robert IS, Patricia CC, Alan KL, Albert S, Baldwin Jr. Role of transcriptional activation of IB in mediation of immunosuppression by glucocorticoids. Science $1995 ; 270: 283-86$.

Robinson DS, Kay AB, Wardlaw AJ. Eosinophils. Clin Allergy Immunol 2002;16:4375.

Romeis B. Mikroskopische Technik. Munich: R Oldenbourg, 1948;1498-99.

Rothenberg ME, Ownbey R, Mehlop PD, Loiselle PM, van de Rijn M, Bonventre JV, Oettgen HC, Leder P, Luster AD. Eotaxin triggers eosinophil selective chemotaxis and calcium flux via a distinct receptor and induces pulmonary eosinophilia inthe presence of IL-5. Molecular Medicine 2:334-48, 1996.

Rothenberg ME. Eosinophilia. N Engl J Med 1998;338:1592-1600.

Rugai E, Mattos T, Brisola AP. A new technique for the isolation of nematode larvae from feces: modification of Baermann's method. Rev Inst Adolfo Lutz 1954;14:5-8.

Schaeffer MW, Buell JF, Gupta M, Conway GD, Akhter SA, Wagoner LE. Strongyloides hyperinfection syndrome after heart transplantation: case report and review of the literature. J Heart Lung Transplant 2004 Jul;23(7):905-11. 
Schmid-Grendelmeier P, Altznauer F, Fischer B, Bizer C, Straumann A, Menz G, Blaser K, Wuthrich B, Simon H. Eosinophils express functional IL-13 in eosinophilic inflammatory diseases. J Immunol 2002;169:1021-27.

Serra MF, Barreto EO, Silva JP, Azevedo V, Mota EM, Pelajo-Machado M, Lucena S, Pires AL, Carvalho V, Cordeiro RS, Lenzi HL, Silva PM, Martins MA. Kinetics of eosinophil and lgE-mast cell changes following infection with Angiostrongylus costaricensis in Wistar rats. Parasite Immunol. 2003 Mar;25(3):169-77.

Siddiqui AA, Stanley CS, Skelly PJ, Berk SL. A cDNA encoding a nuclear hormone receptor of the steroid/thyroid hormone-receptor superfamily from the human parasitic nematode Strongyloides stercoralis. Parasitol Res. 2000 Jan;86(1):24-9.

Silveira MR, Nunes KP, Cara DC, Souza DG, Corrêa A Jr, Teixeira MM, NegrãoCorrêa D. Infection with Strongyloides venezuelensis induces transient airway eosinophilic inflammation, an increase in immunoglobulin $E$, and hyperresponsiveness in rats. Infect Immun 2002;70(11):6263-72.

Smith B, Verghese A, Guiterrez C, Dralle W, Berk SL. Pulmonary strongyloidiasis. Diagnosis by sputum gram stain. Pulmonary strongyloidiasis. Diagnosis by sputum gram stain. Am J Med 1985;79:663-66.

Swartz JM, Dyer KD, Cheever AW, Ramalingam T, Pesnicak LD, Joseph B; Lee JJ, Nancy A, Foster PS. Schistosoma mansoni infection in eosinophil lineage-ablated mice. Blood 108: 2420-27, 2006.

Takamure A. Migration route of Strongyloides venezuelensis in rodents. Int $\mathrm{J}$ Parasitol 1995;25(8):907-11.

Valente O, Atallah AN. Efeitos Metabólicos e Manuseio Clínico dos Corticosteróides. In:Atualização terapêutica: manual prático de diagnóstico e tratamento. Prado FC, et al.20ª ed. São Paulo: Artes Médicas, 2001:1521-23.

Viney ME, Lok JB. Strongyloides spp. WormBook 2007;23:1-15.

Voehringer D, Reese TA, Huang X, Shinkai K, Locksley RM. Type 2 immunity is controlled by IL-4/IL-13 expression in hematopoietic non-eosinophil cells of the innate immune system. J Exp Med. 2006 Jun 12;203(6):1435-46.

Wallen N, Kita H, Weiller D, Gleich GJ. Glucocorticoids inhibit cytokine-mediated eosinophil survival. J Immunol 1991;147:3490-5.

Wardlaw AJ. Molecular basis for selective eosinophil trafficking in asthma: A multistep paradigm. J Allergy Clin Immunol 1999;104:917-26.

Wertheim G. Growth and development of Strongyloides venezuelensis Brumpt, 1934 in the albino rat. Parasitology 1970;61:381-8. 
Wong DT, Weller PF, Galli SJ, Elovic A, Rand TH, Gallagher GT, Chiang T, Chou MY, Matossian K, McBride J, Todd R. Human eosinophils express transforming growth factor- $\beta$. J Exp Med 1990;172:673-81.

Wynn TA, Cheever AW. Cytokine regulation of granuloma formation in schistosomiasis. Current Opinion in Immunology 7: 505-511, 1995.

Yamaguchi M, Lantz CS, Oettgen HC, Katona IM, Flemming T, Miyajima I, Kinet JP, Galli SJ. IgE enhances mouse mast cell FceRI expression in vitro and in vivo: evidence for a novel amplification mechanism in IgE-dependent reactions. J Exp Med 1997;185:663-72.

Yee A, Boylen CT, Noguchi T, Klatt EC, Sharma OP. Fatal Strongyloides stercoralis infection in a patient receiving corticosteroids. West J Med 1987;146:363-64. 


\section{ANEXOS \\ COLORAÇÕES}

\section{Hematoxilina e eosina}

As lâminas foram desparafinizadas em série decrescente de álcoois e lavadas em água corrente. Em seguida, coradas pela hematoxilina de Harris por 35 minutos. Lavadas em água corrente diferenciadas em solução álcool-ácido a 1\% e lavadas por 15 minutos. Após, foram coradas com solução de eosina-floxina por 10 a 30 segundos e passadas em álcool 95\% para a retirada do excesso de corante. As lâminas foram desidratadas, diafanizadas e montadas.

\section{Hematoxilina de Harris}

As lâminas são deixadas na solução hematoxilina por 5 a 8 segundos e lavadas com 2 trocas de água corrente. Em seguida, são passadas pela água amoniacal por 30 segundos e lavadas com 2 trocas de água corrente. Por último, são desidratadas, diafanizadas e montadas.

\section{Reticulina de Gomori}

As lâminas foram desparafinizadas e tratadas pela solução de Permanganato por 1 minuto. Lavadas em água corrente por 5 minutos. Depois diferenciadas pela solução de Metabissulfito por 1 minuto. Lavadas em água corrente por 5 minutos. Tratadas pela solução de Ferro Amoniacal por 1 minuto. Lavadas por 5 minutos em água corrente e depois em água destilada por 30 segundos cada. Foram tratadas pela Prata Amoniacal por 1 minuto e lavadas em água destilada por 10 segundos. Depois foram tratadas pela formalina $20 \%$ por 3 
minutos. Lavadas em água corrente por 3 minutos e tratadas pela solução de Cloreto de ouro por 10 minutos. Lavadas em água destilada por 5 minutos. Depois, foram tratadas pelo Hipossulfito de sódio por 1 minuto. Lavadas em água corrente por 2 minutos. As lâminas foram desidratadas e montadas.

\section{Luna}

As lâminas foram desparafinizadas e hidratadas em álcool 95\%. Depois foram coradas com fucsina aldeídica durante 30 minutos. Enxaguadas em álcool a 95\%. Depois foram coradas pela hematoxilina férrica de Weigert durante 1 minuto. Depois foram lavadas em água corrente durante 10 minutos. Enxaguadas com álcool a 95\%. Contrastadas com a solução de alaranjado de metila durante 5 minutos. Desidratadas através do álcool etílico a 95\%, álcool absoluto e xilol, 2 minutos de cada um. As lâminas foram montadas em bálsamo. 


\section{REAGENTES E SOLUÇÕES}

\section{Solução salina a $0,9 \%$}

Foram dissolvidos $9 \mathrm{~g}$ de $\mathrm{NaCl}$ em 1 litro de água destilada.

\section{PBS (Tampão Salina Fosfato)}

Foram dissolvidos $8,17 \mathrm{~g}$ de $\mathrm{NaCl}, 0,36 \mathrm{~g}$ de fosfato de sódio monobásico, 1,05g de fosfato de sódio dibásico e completado para um volume final de 1 litro com água destilada. $\mathrm{O} \mathrm{pH}$ foi ajustado para 7,4 com $\mathrm{NaOH} 2 \mathrm{M}$.

BSA (Albumina Bovina) utilizada na diluição de anticorpos primários:

Solução A: 5,0g de BSA e $100 \mathrm{~mL}$ de água destilada.

Solução B: $1,0 \mathrm{~g}$ de $\mathrm{NaN}_{3}$ (azida sódica) e $20 \mathrm{~mL}$ de água destilada.

Solução de uso: $1,25 \mathrm{~mL}$ da solução $A$, mais $2,5 \mathrm{~mL}$ da solução $B$, e $59 \mathrm{~mL}$ de $P B S$ $0,1 \mathrm{M} \mathrm{pH} 7,4$. Conservar em geladeira à $4^{\circ} \mathrm{C}$.

TRIPSINA 0,25\%

Diluir $0,025 \mathrm{~g}$ de tripsina em $10 \mathrm{ml}$ de PBS $0,1 \mathrm{M} \mathrm{pH} \mathrm{7,4.}$ 